\title{
DEFLATION IN ASIA: SHOULD THE DANGERS BE DISMISSED?
}

Barry Eichengreen, Donghyun Park, and Kwanho Shin

NO. 490

July 2016
ADB ECONOMICS WORKING PAPER SERIES 


\section{ADB Economics Working Paper Series}

\section{Deflation in Asia: Should the Dangers Be Dismissed?}

Barry Eichengreen, Donghyun Park, and Kwanho Shin

No. 490 | July 2016
Barry Eichengreen (eichengr@econ.berkeley.edu) is George C. Pardee and Helen N. Pardee professor of Economics and professor of Political Science at the Department of Economics, UC Berkeley. Donghyun Park (dpark@adb.org) is principal economist at the Economic Research and Regional Cooperation Department, Asian Development Bank. Kwanho Shin (khshin@korea.ac.kr) is professor at the Department of Economics, Korea University. 
(C) 2016 Asian Development Bank

6 ADB Avenue, Mandaluyong City, 1550 Metro Manila, Philippines

Tel +632632 4444; Fax +6326362444

www.adb.org

Some rights reserved. Published in 2016.

Printed in the Philippines.

ISSN 2313-6537 (Print), 2313-6545 (e-ISSN)

Publication Stock No. WPS168252-2

Cataloging-In-Publication Data

Asian Development Bank.

Deflation in Asia: Should the dangers be dismissed?.

Mandaluyong City, Philippines: Asian Development Bank, 2016.

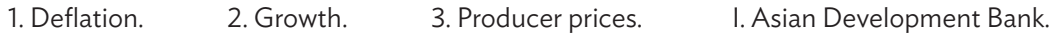

The views expressed in this publication are those of the authors and do not necessarily reflect the views and policies of the Asian Development Bank (ADB) or its Board of Governors or the governments they represent.

ADB does not guarantee the accuracy of the data included in this publication and accepts no responsibility for any consequence of their use. The mention of specific companies or products of manufacturers does not imply that they are endorsed or recommended by ADB in preference to others of a similar nature that are not mentioned.

By making any designation of or reference to a particular territory or geographic area, or by using the term "country" in this document, $A D B$ does not intend to make any judgments as to the legal or other status of any territory or area.

This work is available under the Creative Commons Attribution 3.0 IGO license (CC BY 3.0 IGO)

https://creativecommons.org/licenses/by/3.0/igo/. By using the content of this publication, you agree to be bound by the terms of this license.

This CC license does not apply to non-ADB copyright materials in this publication. If the material is attributed to another source, please contact the copyright owner or publisher of that source for permission to reproduce it. ADB cannot be held liable for any claims that arise as a result of your use of the material.

Attribution - In acknowledging ADB as the source, please be sure to include all of the following information:

Author. Year of publication. Title of the material. (c) Asian Development Bank [and/or Publisher].

URL. Available under a CC BY 3.0 IGO license.

Translations-Any translations you create should carry the following disclaimer:

Originally published by the Asian Development Bank in English under the title [title] (c) [Year of publication] Asian Development Bank. All rights reserved. The quality of this translation and its coherence with the original text is the sole responsibility of the [translator]. The English original of this work is the only official version.

Adaptations-Any adaptations you create should carry the following disclaimer:

This is an adaptation of an original Work (C) Asian Development Bank [Year]. The views expressed here are those of the authors and do not necessarily reflect the views and policies of ADB or its Board of Governors or the governments they represent. ADB does not endorse this work or guarantee the accuracy of the data included in this publication and accepts no responsibility for any consequence of their use.

Please contact publications@adb.org if you have questions or comments with respect to content, or if you wish to obtain copyright permission for your intended use that does not fall within these terms, or for permission to use the ADB logo.

Notes:

1. In this publication, "\$” refers to US dollars.

2. ADB recognizes "China" as the People's Republic of China and "Korea" as the Republic of Korea.

3. Corrigenda to ADB publications may be found at: http://www.adb.org/publications/corrigenda 


\section{CONTENTS}

TABLES AND FIGURES $\quad$ iv

ABSTRACT V V v

$\begin{array}{ll}\text { I. INTRODUCTION } & 1\end{array}$

II. DATA 3

$\begin{array}{ll}\text { III. RESULTS } & 4\end{array}$

IV. WHAT ELSE IS SPECIAL ABOUT THE POST-WORLD WAR II PERIOD?

V. TENTATIVE CONCLUSIONS

$\begin{array}{ll}\text { APPENDIX } & 23\end{array}$

$\begin{array}{lr}\text { REFERENCES } & 27\end{array}$ 


\section{TABLES AND FIGURES}

\section{TABLES}

$1 \quad$ CPI and PPI Inflation Rates, Selected Asian Economies

$2 \quad$ CPI and PPI Deflations: An Overview

3 CPI and PPI Deflations and per Capita Real GDP Growth 7

$4 \quad$ Output Growth and CPI and PPI Deflations II: Regression-Based Correlations 9

$5 \quad$ Output Growth and CPI and PPI Deflations: Regression-Based Correlations (Postwar) 11

$6 \quad$ Change in Output Growth Following CPI, PPI, and Equity-Price Peaks 13

7 Change in 5-Year Output Growth after CPI, PPI, Property-Price, and Equity-Price Peaks (Postwar)

$8 \quad \mathrm{CPI}$ and PPI Deflations and Average Real GDP Growth Rate 16

A.1 Data Availability 23

A.2 Price Peaks $\quad 24$

A.3 Data Sources $\quad 25$

\section{FIGURES}

1 Current Income and Average Log of Real GDP Growth Rate during Deflation and Low Inflation: The Same Slope I

2 Current Income and Average Log of Real GDP Growth Rate during Deflation and Low Inflation: Different Slopes 


\begin{abstract}
Deflation has emerged as a new concern for Asian policy makers. The traditional view is that deflation can lead to a vicious cycle of falling demand and prices, and is thus a dangerous condition. However, another school of thought emphasizes the role of positive supply shocks and takes a more benign view of deflation. In a recent paper that examines the relationship between deflation and economic growth, using consumer prices time series, Borio et al. (2015) find some evidence that casts doubt on the traditional view. In this paper, we revisit the relationship and find some grounds for concern about the harmful effect of deflation on growth.
\end{abstract}

Keywords: deflation, growth, producer prices

JEL code: E31 


\section{INTRODUCTION}

Deflation is a relatively new phenomenon in Asia. Where deflation was once regarded as a peculiarly Japanese problem, the phenomenon-and concern over it-has spread to other Asian economies. Visibly slower growth since the global financial crisis has combined with weak global oil and other commodity prices to contain inflationary pressures. While this provided the region's central banks with room for countercyclical monetary expansion, there are concerns that inflation is now too low. Although consumer price inflation generally remains positive, producer prices fell in 2015 in a number of economies in the region, including the People's Republic of China (PRC), India, the Republic of Korea, Malaysia, the Philippines, and Thailand (Table 1).

Table 1: CPI and PPI Inflation Rates, Selected Asian Economies

\begin{tabular}{lccccc}
\hline & \multicolumn{2}{c}{ CPI Inflation } & & \multicolumn{2}{c}{ PPI Inflation } \\
\cline { 2 - 3 } \cline { 5 - 6 } Economy & 2015 & $\operatorname{Dec} 2015$ & & 2015 & Dec 2015 \\
\hline People's Republic of China & 1.4 & 1.6 & & -5.2 & -5.9 \\
Hong Kong, China & 3.0 & 2.5 & & -2.7 & -3.2 \\
India & 4.9 & 5.6 & & -2.7 & -0.7 \\
Japan & 0.8 & 0.3 & -2.2 & -3.4 \\
Republic of Korea & 0.7 & 1.3 & & -4.0 & -4.0 \\
Malaysia & 2.1 & 2.7 & & -4.8 & -1.6 \\
Philippines & 1.4 & 1.5 & -6.7 & -7.2 \\
Singapore & -0.5 & -0.6 & & -9.1 & -7.7 \\
Thailand & -0.9 & -0.9 & & -4.1 & -2.7 \\
\hline
\end{tabular}

$\mathrm{CPI}=$ consumer price index $\mathrm{PPI}=$ producer price index.

Note: Hong Kong, China's latest PPI inflation rate is Q4 2015 instead of December, due to lack of monthly published data.

Sources: National Bureau of Statistics (PRC); Census and Statistics Department (Hong Kong, China); Statistics Bureau (Japan); Statistics

Korea (Republic of Korea); CEIC Data Company (Philippines and Thailand); Department of Statistics (Singapore).

Indeed, as of February 2016, the PRC had experienced producer price deflation for 47 consecutive months. With a slowing Chinese economy giving rise to talk of renminbi depreciation, there are growing fears that deflation in the PRC will be transmitted to the country's neighbors via lower Chinese export prices. With growth in other parts of the world already slow and now potentially decelerating further, external demand for Chinese and East Asian exports remains subdued, making for further downward pressure on prices. And with interest rates in many Asian economies already low, there is little that central banks can do about it. All this raises the possibility that additional deflation could be in the pipeline.

The traditional view is that deflation is a dangerous condition to be avoided at all cost (see, for example, Fisher 1933 and Friedman and Schwartz 1963 for standard references). Deflation makes domestic-currency debts not indexed to the price level (which in practice means most domesticcurrency debts) more difficult to service and repay. Those difficulties in turn threaten to create balance sheet problems and losses for the creditors, prominent among them domestic banks and other institutional investors. Debtors desperate to avoid incurring the costs of default and renegotiation, for their part, are apt to tighten their belts. Firms therefore curtail their investment projects, while households limit their spending on big ticket items in particular, further weakening demand. 
Expectations of falling prices make even those with the wherewithal to continue investing and consuming delay their purchases in anticipation of still lower prices in the future. For all these reasons, once deflation is allowed to commence, it can gather momentum and will tend to persist. And the impotence of conventional monetary policy at the zero lower bound-together with the inability of central banks to cut interest rates further-means that central banks have little capacity to counter the downward spiral.

Against this view, there have long been voices questioning the conventional wisdom that deflation is a worrisome phenomenon. Prices can decline not just because of negative demand shocks but also because of positive supply shocks.' This benign positive-supply-shock interpretation was the dominant view of producer price deflation in the PRC so long as that country was growing strongly. With total factor productivity rising by fully $6 \%$ per annum, Chinese producers were fully capable of cutting prices and at the same time maintaining profitability. And with their production expanding strongly, it was necessary for a country as large as the PRC to cut prices repeatedly in order to sell its increased output into global markets. None of this, in other words, necessarily represented a problem. The same benign interpretation of recent experience could be applied, to a greater or lesser extent, to other Asian success stories as well. To be sure, now that total factor productivity growth and economic growth more generally appear to be decelerating in the PRC and elsewhere in East Asia, this benign interpretation becomes more difficult to maintain. ${ }^{2}$ But it can still be argued, on this basis, that the dangers of deflation have been overstated.

The principal exponents of this last conclusion are economists at the Bank for International Settlements (Borio and Filardo 2005, Borio et al. 2015). In their 2015 paper, the authors consider the association between the consumer price index $(\mathrm{CPI})$ and the rate of growth of per capita gross domestic product (GDP) since 1870 for a wide range of economies. They distinguish different eras (that of the classical gold standard, the interwar period, the period since World War II) and different kinds of deflation (transient versus persistent). They find few significant differences in the rate of growth of GDP between periods of inflation and deflation, the notable exception being the decade of the Great Depression starting in 1929, a deflationary event that was persistent and, according to the scholarly consensus, dominantly the result of a negative demand shock. ${ }^{3}$ The implication is that researchers have inappropriately generalized the experience of an exceptional period, 1929-1933, when deflation was exceptionally rapid and persistent, to other periods. They have applied the conclusion that deflation must be avoided at all cost also to other circumstances where it is not apposite. $^{4}$

But failure to reject a null hypothesis (in this case, the null hypothesis that there is no significant difference in the growth rate between periods of inflation and deflation) "does not imply that the null is true; the test may simply be not very powerful" (Hodrik 2014). Relatively short time series make it hard to reject a null. The price index may be noisy, where random noise raises standard errors and biases coefficients toward zero..$^{5}$ The price index utilized may not be the one relevant to the consumption and investment decisions of agents; consumers care about consumer prices, while

\footnotetext{
Bordo and Redish (2004) refer to these as "good" and "bad" deflations.

2 Even for the earlier period, Siklos and Zhang (2010) conclude that demand shocks were at least as important (and maybe more important) than supply shocks as a source of Chinese deflation.

3 On the nature of shocks in the Great Depression and the relevance of the debt deflation interpretation see Fackler and Parker (2005).

4 Akeson and Kehoe (2004) draw similar conclusions.

5 Random noise/random errors in the dependent variable (the rate of growth of real per capita GDP) are less troubling from a strictly econometric point of view, but there is also the possibility that noise is not random.
} 
producers presumably care about producer prices. ${ }^{6}$ The further back in time one goes, the more limited is the range of items included in consumer price indices (19th century consumer price indices being heavily based on the cost of food and shelter, or even only food). This reality is reflected in the fact that, possessing relatively abundant information on farm- and factory-gate prices, contemporaries already in the $19^{\text {th }}$ century constructed their own estimates of producer (wholesale) prices, whereas estimates of consumer prices tend to be constructed retrospectively by economic historians, often using relatively fragmentary data and ancillary assumptions.

In this paper, we therefore revisit the association between deflation and economic growth using time series for producer prices. We find more evidence than in other recent studies, cited above, that deflation is damaging. We find more evidence that the damaging effects are not limited to the interwar period or the Great Depression years 1929-1938. Evidence of inferior growth performance in periods of deflation comes through more clearly when we exclude episodes of relatively high inflation, which can also be disruptive to growth. No study of this sort can definitively answer the question of whether or not deflation should be regarded as a problem. But, compared to other recent work, our findings provide more grounds for worrying.

\section{DATA}

Our data start with those used in the Borio et al. (2015) study. These cover 38 now advanced countries and emerging markets. ${ }^{7}$ The panel is unbalanced: country coverage improves over time. (See Appendix Table A.1 for details.) After updating their data, we added series for producer prices from Global Financial Data (GFD). GFD assembles its series on producer prices from a variety of different sources. For the post-World War II period, these tend to be government-generated time series, for some countries for the price of manufactures, for other countries for the price of commodities (both industrial and agricultural) more generally. Limiting coverage to the prices of manufactured goods matters relatively little for places like Japan where agriculture is only a small sector (and where the producer price index, or PPI) covers only the factory-gate price of manufactures). For other countries, including those where agriculture remains more consequential, coverage tends to be wider; in the case of the United States (US), for example, the Bureau of Labor Statistics seeks to include the "entire marketed output of U.S. producers" (BLS 2016).

For earlier historical periods, the producer price indices (PPI) provided by GFD are also known as wholesale price indices. It is worth asking whether the two series-wholesale price indices and producer price indices-are in fact comparable to one another. For some countries, like the US, it is easy to verify that this is the case. The US Bureau of Labor Statistics describes how the BLS series for the prices of goods received by and traded among producers was referred to as the wholesale price index from the inception of public provision in 1902 until 1978, when the series was renamed as the PPI. That change in name "did not include a change in index methodology, and the continuity of the

6 A related literature argues that wage stickiness is an important factor in the business cycle, with real wages rising, countercyclically and counterproductively, precisely when activity turns down due to negative demand shocks, and that it is nominal wages relative to producer prices that matter for firms' employment and production decisions. Contributions to this literature generally find that PPI-deflated real wages are countercyclical, and therefore provide a channel through which demand shocks affect the economy, while CPI-deflated real wages are acyclical. See Swanson (2004) and Messina, Strozzi, and Turunen (2009).

7 These data were assembled from GFD, Brian Mitchell's (1993) compendium of International Historical Statistics and Schularick and Taylor (2012). See Appendix Table A.3 for detailed information on sources of other data as well as information on prices. 
price index data was unaffected" (BLS 2016). ${ }^{8}$ Upon inauguration in 1902, the BLS constructed wholesale price indices back to 1890 using the same methodology. The source of US data in GFD for the years immediately prior to 1890 is not entirely clear, but these are most likely drawn from pioneering and still definitive index building by Warren and Pearson (1933), which followed analogous methods.

This effort to recover the sources of commonly used series could similarly be undertaken for other countries. It is a reminder that there may have been repeated changes in commodity coverage, definition and in some cases methodology, affecting both the CPI and the PPI, creating the appearance of changes in the cyclical sensitivity of what are superficially the same price aggregates.

It is also worth reflecting on how the behavior of consumer and producer price indices is likely to differ. By definition, consumer price indices measure price changes from the point of view of the buyer, while producer price indices measure them from the point of view of the seller, where sellers' and purchasers' prices will differ because of government subsidies, sales and excise taxes, and distribution costs. Insofar as taxes, subsidies and perhaps also distribution costs are slow to change, consumer prices may exhibit less volatility and more persistence than producer prices. Insofar as one is interested in the impact of deflation on production decisions, it makes most sense to focus on producer prices. Insofar as one is interested in spending decisions, it will make sense to focus on a combination of consumer prices and producer prices (because the former are most relevant to the spending decisions of households, whereas both will be relevant to the spending decisions of firms). ${ }^{9}$

\section{RESULTS}

Table 2, following Borio et al. (2015), shows summary statistics for both CPI and PPI inflation/deflation in different eras and under different monetary regimes. Following Borio et al. 2015, we exclude observations from the war years 1914-1918 and 1939-1945 and in the case of Spain, observations from the Civil War years 1936-1939. We also exclude observations from years of extremely high inflation, i.e. higher than $100 \%$.

The correlation between the change in the PPI and the CPI, at 0.88 , is high in general but noticeably lower in the classical gold standard years than subsequent periods. The correlation between the two measures of changes in the price level is higher in years when the CPI is going up than in years when it is going down, pointing in particular to sensitivity in the data for how deflationary periods are identified (and for how deflationary such periods were). This last pattern is due mainly to the much lower correlation of the two inflation measures in years when prices were going down in the period after World War II; evidently, the incidence of episodes of CPI and WPI deflation has been very different since World War II, but not so different before. There are well more than twice as many years of PPI as CPI deflation after World War II, whereas the number of years of PPI and CPI inflation in earlier periods is much more similar. ${ }^{10}$ This suggests that relying on a single index for measuring deflation is likely to be especially problematic when focusing on the post-World War II years.

8 There is, however, some slightly unsettling commentary in BLS 1966 that the term "wholesale" is used because producers tend to sell to one another in relatively large quantities, which in turn suggests that coverage in the earlier years of the official series was less complete than it became later.

9 The logic for the last statement in the text is that a firm considering an investment decision will presumably consider the relationship between what it can expect to earn from additional capacity and therefore additional sales (and hence prices from the seller's point of view) but also the cost of the relevant inputs (and hence prices from the buyer's point of view).

10 The contrast is even stronger when we consider periods of persistent deflation, as described below. 
Table 2: CPI and PPI Deflations: An Overview

\begin{tabular}{|c|c|c|c|c|c|c|c|c|c|}
\hline & & & Full Sample & $\begin{array}{c}\text { Classical } \\
\text { Gold } \\
\text { Standard } \\
(1870-1913)\end{array}$ & $\begin{array}{c}\text { Interwar } \\
(1920-1938)\end{array}$ & $1920-1928$ & 1929-1938 & $\begin{array}{c}\text { Great Depression } \\
(1930-1933)\end{array}$ & $\begin{array}{c}\text { Postwar } \\
(1947-2014) \\
\end{array}$ \\
\hline \multirow{8}{*}{ All } & \multirow{2}{*}{ CPI } & Number of inflation years & 2,940 & 341 & 269 & 122 & 147 & 25 & 2,332 \\
\hline & & Number of deflation years & 658 & 265 & 248 & 102 & 146 & 89 & 145 \\
\hline & \multirow{2}{*}{ PPI } & Number of inflation years & 2,443 & 328 & 201 & 76 & 125 & 26 & 1,914 \\
\hline & & Number of deflation years & 921 & 288 & 244 & 111 & 133 & 75 & 389 \\
\hline & \multirow{2}{*}{ CPI } & Average duration (years) & 1.87 & 1.96 & 2.25 & 1.96 & 2.25 & 2.62 & 1.36 \\
\hline & & Average rates $(\%)$ & -4.05 & -3.82 & -5.62 & -6.75 & -4.82 & -6.13 & -1.81 \\
\hline & \multirow{2}{*}{ PPI } & Average duration (years) & 1.77 & 2.07 & 2.35 & 2.09 & 2.11 & 2.14 & 1.41 \\
\hline & & Average rates (\%) & -5.03 & -4.91 & -8.78 & -10.12 & -7.66 & -9.85 & -2.78 \\
\hline \multirow{6}{*}{ Persistent deflations } & \multirow{3}{*}{ CPI } & Number & 76 & 41 & 30 & 20 & 27 & 27 & 5 \\
\hline & & Average duration (years) & 7.21 & 6.56 & 8.37 & 6.15 & 4.74 & 3.37 & 5.60 \\
\hline & & Average rates (\%) & -3.27 & -2.49 & -4.31 & -4.04 & -4.57 & -5.62 & -1.40 \\
\hline & \multirow{3}{*}{ PPI } & Number & 92 & 36 & 27 & 25 & 24 & 24 & 29 \\
\hline & & Average duration (years) & 7.38 & 7.67 & 9.85 & 6.04 & 4.79 & 3.21 & 4.72 \\
\hline & & Average rates (\%) & -4.30 & -3.16 & -6.36 & -5.99 & -6.84 & -8.41 & -2.63 \\
\hline \multirow{3}{*}{ Correlation } & & All & 0.88 & 0.30 & 0.71 & 0.75 & 0.69 & 0.70 & 0.92 \\
\hline & & CPI inflation & 0.89 & 0.08 & 0.54 & 0.62 & 0.57 & 0.77 & 0.92 \\
\hline & & CPI deflation & 0.52 & 0.14 & 0.69 & 0.78 & 0.46 & 0.48 & 0.14 \\
\hline \multirow[t]{2}{*}{$\begin{array}{l}\text { Number of economies } \\
\text { in sample }\end{array}$} & $\mathrm{CPI}$ & & 38 & 19 & 32 & 28 & 32 & 30 & 38 \\
\hline & PPI & & & 38 & 20 & 29 & 23 & 29 & 28 \\
\hline
\end{tabular}

$\mathrm{CPI}=$ consumer price index, $\mathrm{PPI}=$ producer price index.

Note: Economies in sample: Argentina; Australia; Austria; Belgium; Brazil; Canada; Chile; People’s Republic of China; Colombia; Denmark; Finland; France; Germany; Greece; Hong Kong, China; Ireland; Italy; Japan; Republic of Korea; Malaysia; Mexico; The Netherlands; New Zealand; Norway; Peru; Philippines; Portugal; Singapore; South Africa; Spain; Sweden; Switzerland; Thailand; Turkey; United Kingdom; United States; Uruguay; and Venezuela. Full sample excludes observations from the war years 1914-1918 and 1939-1945 and in the case of Spain, observations from the Civil War 1936-1939. We also excluded, through the periods, observation from years with inflations higher than $100 \%$. Persistent deflations are defined as years following a price peak that is identified as a turning point exceeding price index levels in the preceding and subsequent 5 years. Duration of persistent deflations is calculated from peak to trough.

Sources: CPI and PPI are from Global Financial Database, International Historical Statistics 1750-2010 and International Financial Statistics, and per capita real GDP, from the Maddison Project and World Development Indicators. 
The average rate of change of the price level in deflation years is consistently greater (in absolute value) when we consider the PPI than when we consider the CPI. PPI deflation is half again as fast in these episodes; the differential is roughly the same regardless of subperiod. All this is consistent with the idea that the consumer price index is stickier than the producer price index, including in the downward direction.

Persistent deflations are defined, following Borio et al. 2015, as periods following price-level peaks when prices fall significantly. ${ }^{11}$ We identify more years of deflation of this persistent type when we consider the PPI rather than the CPI. The difference is accounted for almost entirely by the years since 1947. When using the CPI, there is only a small handful (five) number of persistent deflations, so measured, in the 38 economies in the sample. But when using the PPI there are 29 such deflations. Again, this suggests that relying only on the change in the CPI as a gauge of persistent deflation may be especially problematic for the post-World War II period.

Table 3 tabulates the growth rate of GDP per capita in inflation and deflation years using both the CPI and PPI. We divide the inflation years into years of high and low inflation, according to whether inflation is greater or less than $10 \%$, on the grounds that the disruptive effects of inflation are likely to be more pronounced when price increases are relatively rapid. We further distinguish years of deflation from years of persistent deflation, as defined above.

The summary statistics in the table confirm that growth is slower on average in years of high inflation than years of low inflation. The null of no difference in the average GDP growth rate is rejected in the full sample, which is mainly driven from the experiences of the postwar era. Over the full sample, growth is significantly slower in periods of deflation than in periods of high inflation, whether inflation is measured using the PPI or the CPI. It is significantly slower in periods of deflation than in periods of low inflation, again regardless of the price index used.

At a more disaggregated level, our results for CPI inflation are similar to those of Borio et al. (2015), except where they report that the null of no difference in the average GDP growth rate in the Great Depression years (1930-1933) cannot be rejected even at the 10\% level, our statistics reject this null at the $1 \%$ level of confidence when we compare low inflation with deflation. When we consider the PPI rather than the CPI, we reject the null for the post-World War II. Again, this points to the potential sensitivity of findings to the particular price index used, particularly for the years since World War II.

11 While Borio et al. (2015) defined peaks by using the 5-year moving average, we simply defined peaks as turning points exceeding price index levels in the preceding and subsequent 5 years. The reason for this is that we could not identify the same peaks as Borio et al. (2015) if we use 5-year moving averages. Our methodology does not identify exactly the same peak years, but generates reasonably well-matched peaks. See Appendix Table A.2 for the list of peak years. 
Table 3: CPI and PPI Deflations and per Capita Real GDP Growth

\begin{tabular}{|c|c|c|c|c|c|c|c|c|c|}
\hline & & & Full Sample & $\begin{array}{c}\text { Classical } \\
\text { Gold } \\
\text { Standard } \\
(1870-1913)\end{array}$ & $\begin{array}{c}\text { Interwar } \\
(1920-1938)\end{array}$ & $1920-1928$ & $1929-1938$ & $\begin{array}{c}\text { Great } \\
\text { Depression } \\
(1930-1933)\end{array}$ & $\begin{array}{c}\text { Postwar } \\
(1947-2014)\end{array}$ \\
\hline \multirow{8}{*}{$\begin{array}{l}\text { Average per capita real } \\
\text { GDP growth }\end{array}$} & \multirow{4}{*}{ CPI } & (1) High inflation & 2.31 & 1.17 & 3.02 & 3.49 & 2.13 & -2.90 & 2.28 \\
\hline & & (2) Low inflation & 2.74 & 1.60 & 3.70 & 3.43 & 3.87 & 2.46 & 2.83 \\
\hline & & (3) Deflation & 1.17 & 1.17 & 0.36 & 2.20 & -0.90 & -3.03 & 2.55 \\
\hline & & (4) Persistent deflation & 0.85 & 0.98 & 0.44 & 2.42 & -1.41 & -3.09 & 3.25 \\
\hline & \multirow{4}{*}{ PPI } & (5) High inflation & 2.42 & 1.51 & 4.66 & 5.87 & 3.76 & 3.47 & 2.28 \\
\hline & & (6) Low inflation & 2.75 & 1.86 & 3.72 & 4.60 & 3.23 & -1.82 & 2.84 \\
\hline & & (7) Deflation & 1.40 & 1.29 & 0.42 & 2.07 & -0.91 & -3.36 & 2.10 \\
\hline & & (8) Persistent deflation & 1.22 & 1.20 & 0.63 & 2.50 & -1.76 & -3.89 & 2.36 \\
\hline \multirow{12}{*}{ Mean equality test } & \multirow{2}{*}{ (1) vs (2) } & Difference & $-0.43^{* *}$ & -0.43 & -0.68 & 0.06 & -1.74 & -5.37 & $-0.54^{* * *}$ \\
\hline & & & {$[0.01]$} & {$[0.65]$} & {$[0.37]$} & {$[0.95]$} & {$[0.15]$} & {$[0.19]$} & {$[0.00]$} \\
\hline & \multirow{2}{*}{ (1) vs (3) } & Difference & $1.14^{* * *}$ & 0.00 & $2.67^{* * *}$ & 1.29 & $3.03^{* *}$ & 0.13 & -0.27 \\
\hline & & & {$[0.00]$} & {$[1.00]$} & {$[0.00]$} & {$[0.22]$} & {$[0.04]$} & {$[0.97]$} & {$[0.53]$} \\
\hline & \multirow{2}{*}{ (2) vs (3) } & Difference & $1.57^{* * *}$ & 0.43 & $3.34^{* * *}$ & 1.23 & $4.78^{* * *}$ & $5.50^{* * *}$ & 0.27 \\
\hline & & & {$[0.00]$} & {$[0.23]$} & {$[0.00]$} & {$[0.13]$} & {$[0.00]$} & {$[0.00]$} & {$[0.31]$} \\
\hline & \multirow{2}{*}{ (5) vs (6) } & Difference & $-0.33^{*}$ & -0.35 & 0.95 & 1.27 & 0.53 & 5.29 & $-0.56^{* * *}$ \\
\hline & & & {$[0.05]$} & {$[0.62]$} & {$[0.33]$} & {$[0.34]$} & {$[0.70]$} & {$[0.26]$} & {$[0.00]$} \\
\hline & \multirow{2}{*}{ (5) vs (7) } & Difference & $1.02^{* * *}$ & 0.22 & $4.24^{* * *}$ & $3.80^{* * *}$ & $4.67^{* * *}$ & $6.84^{* * *}$ & 0.18 \\
\hline & & & {$[0.00]$} & {$[0.77]$} & {$[0.00]$} & {$[0.00]$} & {$[0.00]$} & {$[0.03]$} & {$[0.49]$} \\
\hline & \multirow{2}{*}{ (6) vs (7) } & Difference & $1.35^{* * *}$ & $0.57^{*}$ & $3.29^{* * *}$ & $2.53^{* * *}$ & $4.14^{* * *}$ & 1.54 & $0.74^{* * *}$ \\
\hline & & & {$[0.00]$} & {$[0.06]$} & {$[0.00]$} & {$[0.00]$} & {$[0.00]$} & {$[0.40]$} & {$[0.00]$} \\
\hline Number of economies & CPI & & 38 & 19 & 32 & 28 & 32 & 30 & 38 \\
\hline In sample & PPI & & 38 & 20 & 29 & 23 & 29 & 28 & 38 \\
\hline
\end{tabular}

$\mathrm{CPI}=$ consumer price index, $\mathrm{GDP}=$ gross domestic product, $\mathrm{PPI}=$ producer price index

Notes: Economies in sample are listed in note to Table 1. High and low inflations refer to inflation higher than $10 \%$ and inflation less than $10 \%$, respectively. Persistent deflations are defined the same as in Table 1. Difference for (1) vs (2) is calculated by subtracting the average per capita real GDP growth rate during the latter period, (1) from that during the former period, (2). Other differences are calculated similarly. Numbers in brackets are $p$-values and ${ }^{* * *} *^{* * *}$ denotes mean equality rejection with significance at the $10 / 5 / 1 \%$ level.

Sources: CPI and PPI are from Global Financial Database, International Historical Statistics 1750-2010 and International Financial Statistics, and per capita real GDP, from the Maddison Project and World Development Indicators. 
Table 4 uses regression analysis to relate inflation/deflation to economic growth. Following Borio et al. (2015), we estimate panel regressions with country fixed effects, allowing differences across countries. ${ }^{12}$ We include also the change in equity prices, as in Borio et al. (2015), to capture and control for separate effects of asset price deflation (which some argue is a greater problem than consumer price and producer price deflation). In the full sample, the coefficients on the change in both the CPI and the PPI are positive and highly significant, consistent with the idea that deflation is bad for economic growth. But for the CPI, all the explanatory power derives from the association of deflation with recession in the interwar period; the coefficients on the change in CPI inflation are positive and highly significant for this subperiod, but they do not approach statistical significance at conventional confidence levels for any other subperiod. This suggests that deflation was depressing during the Great Depression but not more generally, consistent with the findings of Borio et al. (2015).

The picture is different, however, for the PPI. Changes in the PPI are significantly related to growth, in the direction anticipated by the disruptive-deflation hypothesis, not just in the interwar period but also under the classical gold standard and since World War II, although the estimated coefficients are largest during the interwar period. This set of results also highlights the role of deflation in the Great Depression, but it is at odds with the view that deflation has been depressing only during the Great Depression.

In addition, including the change in equity prices and the interaction of the change in equity prices with a dummy variable for when that change is negative does not make the depressing effect of PPI deflation go away. It does confirm, however that falling equity prices make the resulting contraction of output worse. ${ }^{13}$

Restricting the sample to include only low inflation years (only years when inflation was less than $3 \%$ or, alternatively, less than $1 \%$ ) does not change the results materially. The main difference from the baseline estimates is that the coefficient on the change in the CPI is now significantly positive at the 10\% level or better under the gold standard (1870-1913) as well as in the interwar years, whereas there is no association of PPI inflation with growth under the gold standard.

12 While the growth rate of per capita GDP can differ across countries of different levels of development, we believe that the country fixed effects also take care of this difference as well especially when we run the regression for the subsample period.

13 That falling equity prices are depressing is consistent with the findings of Borio et al. (2015). That there is also a separate effect of deflation itself (when measured by the change in the PPI) is not. 
Table 4: Output Growth and CPI and PPI Deflations II: Regression-Based Correlations

(a) No restrictions to inflation

\begin{tabular}{|c|c|c|c|c|c|c|c|c|c|c|c|c|c|c|c|c|}
\hline & \multicolumn{4}{|c|}{ Full Sample } & \multicolumn{4}{|c|}{$\begin{array}{c}\text { Classical Gold Standard } \\
(1870-1913)\end{array}$} & \multicolumn{4}{|c|}{ Interwar (1920-1938) } & \multicolumn{4}{|c|}{ Postwar (1947-2014) } \\
\hline & (1) & $(2)$ & (3) & (4) & (5) & $(6)$ & $(7)$ & $(8)$ & $(9)$ & (10) & $(11)$ & $(12)$ & $(13)$ & (14) & (15) & (16) \\
\hline$\triangle \mathrm{CPI}$ & $\begin{array}{r}0.10^{* * *} \\
{[0.024]}\end{array}$ & $\begin{array}{r}0.10^{* * *} \\
{[0.023]}\end{array}$ & & & $\begin{array}{r}0.04 \\
{[0.073]}\end{array}$ & $\begin{array}{r}0.04 \\
{[0.076]}\end{array}$ & & & $\begin{array}{r}0.16^{* * *} \\
{[0.029]}\end{array}$ & $\begin{array}{r}0.15^{* * *} \\
{[0.028]}\end{array}$ & & & $\begin{array}{r}0.03 \\
{[0.029]}\end{array}$ & $\begin{array}{r}0.04 \\
{[0.028]}\end{array}$ & & \\
\hline$\triangle \mathrm{PPI}$ & & & $\begin{array}{l}0.10^{* * *} \\
{[0.017]}\end{array}$ & $\begin{array}{l}0.10^{* * *} \\
{[0.017]}\end{array}$ & & & $\begin{array}{r}0.10^{*} \\
{[0.046]}\end{array}$ & $\begin{array}{r}0.10^{*} \\
{[0.045]}\end{array}$ & & & $\begin{array}{r}0.13^{* * *} \\
{[0.022]}\end{array}$ & $\begin{array}{r}0.13^{* * *} \\
{[0.022]}\end{array}$ & & & $\begin{array}{r}0.05^{* *} \\
{[0.022]}\end{array}$ & $\begin{array}{r}0.06^{* *} \\
{[0.021]}\end{array}$ \\
\hline$\triangle \mathrm{EP}$ & $\begin{array}{r}0.01^{* * *} \\
{[0.004]}\end{array}$ & $\begin{array}{r}-0.00 \\
{[0.006]}\end{array}$ & $\begin{array}{r}0.01^{* * *} \\
{[0.004]}\end{array}$ & $\begin{array}{r}-0.01 \\
{[0.006]}\end{array}$ & $\begin{array}{r}0.02 \\
{[0.019]}\end{array}$ & $\begin{array}{r}0.01 \\
{[0.034]}\end{array}$ & $\begin{array}{r}-0.00 \\
{[0.015]}\end{array}$ & $\begin{array}{r}-0.02 \\
{[0.014]}\end{array}$ & $\begin{array}{l}0.08^{* * *} \\
{[0.011]}\end{array}$ & $\begin{array}{r}0.03 \\
{[0.022]}\end{array}$ & $\begin{array}{l}0.06^{* * *} \\
{[0.011]}\end{array}$ & $\begin{array}{r}0.00 \\
{[0.019]}\end{array}$ & $\begin{array}{r}0.00 \\
{[0.003]}\end{array}$ & $\begin{array}{r}-0.01 \\
{[0.006]}\end{array}$ & $\begin{array}{r}0.00 \\
{[0.003]}\end{array}$ & $\begin{array}{r}-0.01 \\
{[0.006]}\end{array}$ \\
\hline$\triangle E P^{\text {def }}$ & & $\begin{array}{l}0.04^{* * *} \\
{[0.012]}\end{array}$ & & $\begin{array}{l}0.04^{* * *} \\
{[0.012]}\end{array}$ & & $\begin{array}{r}0.01 \\
{[0.065]}\end{array}$ & & $\begin{array}{r}0.05 \\
{[0.036]}\end{array}$ & & $\begin{array}{r}0.10^{* *} \\
{[0.040]}\end{array}$ & & $\begin{array}{r}0.10^{* *} \\
{[0.036]}\end{array}$ & & $\begin{array}{r}0.03^{* *} \\
{[0.012]}\end{array}$ & & $\begin{array}{r}0.03^{* *} \\
{[0.012]}\end{array}$ \\
\hline $\begin{array}{l}\text { Observations } \\
\mathrm{R}^{2} \\
\text { Number of economies }\end{array}$ & $\begin{array}{r}2,311 \\
0.044\end{array}$ & $\begin{array}{r}2,311 \\
0.053\end{array}$ & $\begin{array}{r}2,217 \\
0.069\end{array}$ & $\begin{array}{r}2,217 \\
0.078\end{array}$ & $\begin{array}{r}371 \\
0.007\end{array}$ & $\begin{array}{r}371 \\
0.007\end{array}$ & $\begin{array}{r}332 \\
0.032\end{array}$ & $\begin{array}{r}332 \\
0.036\end{array}$ & $\begin{array}{r}295 \\
0.250\end{array}$ & $\begin{array}{r}295 \\
0.267\end{array}$ & $\begin{array}{r}293 \\
0.237\end{array}$ & $\begin{array}{r}293 \\
0.256\end{array}$ & $\begin{array}{r}1,645 \\
0.005\end{array}$ & $\begin{array}{l}1,645 \\
0.013\end{array}$ & $\begin{array}{l}1,592 \\
0.017\end{array}$ & $\begin{array}{r}1,592 \\
0.025\end{array}$ \\
\hline in sample & 35 & 35 & 35 & 35 & 11 & 11 & 11 & 11 & 16 & 16 & 16 & 16 & 35 & 35 & 35 & 35 \\
\hline
\end{tabular}

(b) Years of inflation less than $1 \%$

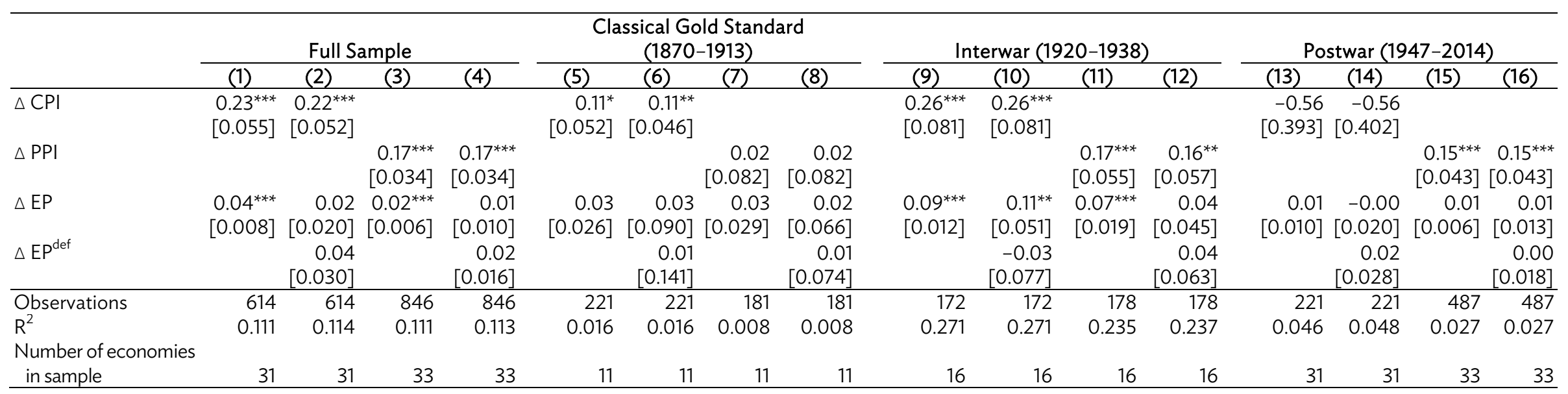


Table 4 continued

(c) Years of Inflation Less Than 3\%

\begin{tabular}{|c|c|c|c|c|c|c|c|c|c|c|c|c|c|c|c|c|}
\hline & \multicolumn{4}{|c|}{ Full Sample } & \multicolumn{4}{|c|}{$\begin{array}{c}\text { Classical Gold Standard } \\
(1870-1913)\end{array}$} & \multicolumn{4}{|c|}{ Interwar (1920-1938) } & \multicolumn{4}{|c|}{ Postwar (1947-2014) } \\
\hline & (1) & (2) & (3) & (4) & (5) & $(6)$ & $(7)$ & (8) & (9) & $(10)$ & $(11)$ & (12) & (13) & $(14)$ & $(15)$ & $(16)$ \\
\hline \multirow[t]{2}{*}{$\triangle \mathrm{CPI}$} & $0.25^{* * *}$ & $0.25^{* * *}$ & & & $0.11^{*}$ & $0.11^{*}$ & & & $0.33^{* * *}$ & $0.32^{* * *}$ & & & 0.13 & 0.14 & & \\
\hline & [0.048] & [0.047] & & & {$[0.053]$} & {$[0.052]$} & & & {$[0.086]$} & {$[0.082]$} & & & {$[0.206]$} & {$[0.209]$} & & \\
\hline \multirow[t]{2}{*}{$\triangle \mathrm{PPI}$} & & & $0.19^{* * *}$ & $0.18^{* * *}$ & & & 0.04 & 0.04 & & & $0.20^{* * *}$ & $0.19^{* * *}$ & & & $0.18^{* * *}$ & $0.18^{* * *}$ \\
\hline & & & {$[0.032]$} & {$[0.032]$} & & & {$[0.063]$} & {$[0.062]$} & & & {$[0.061]$} & {$[0.063]$} & & & {$[0.049]$} & {$[0.048]$} \\
\hline \multirow[t]{2}{*}{$\triangle \mathrm{EP}$} & $0.02^{* * *}$ & 0.00 & $0.02^{* * *}$ & 0.00 & 0.01 & 0.00 & 0.01 & -0.00 & $0.08^{* * *}$ & 0.05 & $0.07^{* * *}$ & 0.04 & $0.01^{* * *}$ & -0.00 & $0.01^{* *}$ & -0.00 \\
\hline & [0.004] & [0.008] & {$[0.004]$} & {$[0.006]$} & {$[0.021]$} & [0.053] & {$[0.026]$} & {$[0.027]$} & [0.013] & {$[0.031]$} & {$[0.022]$} & {$[0.052]$} & [0.004] & [0.008] & {$[0.004]$} & [0.008] \\
\hline \multirow[t]{2}{*}{$\Delta E P^{\text {def }}$} & & $0.04^{* *}$ & & $0.03^{* * *}$ & & 0.03 & & 0.04 & & 0.04 & & 0.05 & & $0.03^{*}$ & & $0.02^{*}$ \\
\hline & & [0.014] & & {$[0.012]$} & & {$[0.091]$} & & {$[0.029]$} & & {$[0.051]$} & & {$[0.069]$} & & {$[0.013]$} & & {$[0.013]$} \\
\hline Observations & 1,270 & 1,270 & 1,245 & 1,245 & 295 & 295 & 232 & 232 & 227 & 227 & 208 & 208 & 748 & 748 & 805 & 805 \\
\hline \multirow{2}{*}{$\begin{array}{l}\mathrm{R}^{2} \\
\text { Number of } \\
\text { economies in } \\
\text { sample }\end{array}$} & 0.093 & 0.100 & 0.109 & 0.115 & 0.010 & 0.011 & 0.005 & 0.007 & 0.293 & 0.296 & 0.274 & 0.278 & 0.015 & 0.020 & 0.037 & 0.041 \\
\hline & 33 & 33 & 35 & 35 & 11 & 11 & 11 & 11 & 16 & 16 & 16 & 16 & 33 & 33 & 35 & 35 \\
\hline
\end{tabular}

$\mathrm{CPI}=$ consumer price index, $\mathrm{PPI}=$ producer price index.

Notes: The dependent variable is the log change of per capita real GDP, $\triangle \mathrm{CPI}, \triangle \mathrm{PPI}$, and $\triangle \mathrm{EP}$ are, respectively, the log change in the $\mathrm{CPI}$, the PPI, and stock prices. $\triangle \mathrm{CPI}{ }^{\text {def }}, \triangle \mathrm{PPI}$ def and $\triangle \mathrm{EP}{ }^{\text {def }}$ are,

respectively, the log changes interacted with a dummy variable that is equal to 1 when the respective price index declines and zero otherwise. Allowing for differences across countries, we include country fixed effects. Numbers in brackets are cluster-robust standard errors and $\left.\right|^{* * *} /{ }^{* * *}$ denotes significance at the 10/5/1\% level.

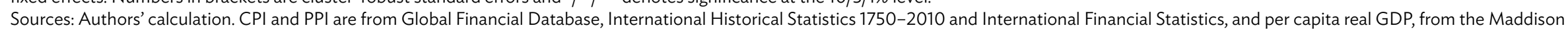
Project and World Development Indicators. The stock price data are from the Global Financial Database, Bloomberg, and Shularick and Taylor (2012). 
Borio et al. (2015) also consider a second measure of asset price inflation, namely the change in property (housing) prices. When we include this variable along with the two measures of price-level inflation and the change in equity prices for the postwar period (the only period for which we have data on housing prices), the results suggest that asset price fluctuations matter more than price-level fluctuations for growth. Like Borio et al. (2015), we obtain a negative and significant coefficient on CPI inflation, inconsistent with the hypothesis of damaging deflation (Table 5.) In contrast, equity prices and property prices both matter, in general and even more when those changes are negative.

Table 5: Output Growth and CPI and PPI Deflations: Regression-Based Correlations (Postwar)

(a) No restrictions

\begin{tabular}{|c|c|c|c|c|c|c|}
\hline & $(1)$ & (2) & (3) & (4) & (5) & (6) \\
\hline$\triangle \mathrm{CPI}$ & $\begin{array}{r}-0.028^{* *} \\
{[0.011]}\end{array}$ & $\begin{array}{r}-0.085^{* * *} \\
{[0.026]}\end{array}$ & $\begin{array}{r}-0.063^{* *} \\
{[0.029]}\end{array}$ & & & \\
\hline$\triangle \mathrm{PPI}$ & & & & $\begin{array}{r}-0.031^{* *} \\
{[0.012]}\end{array}$ & $\begin{array}{r}0.002 \\
{[0.022]}\end{array}$ & $\begin{array}{r}-0.012 \\
{[0.026]}\end{array}$ \\
\hline$\triangle P P$ & & $\begin{array}{c}0.169^{* * *} \\
{[0.016]}\end{array}$ & $\begin{array}{l}0.115^{* * *} \\
{[0.012]}\end{array}$ & & $\begin{array}{l}0.154^{* * *} \\
{[0.014]}\end{array}$ & $\begin{array}{r}0.100^{* * *} \\
{[0.012]}\end{array}$ \\
\hline$\triangle \mathrm{EP}$ & & $\begin{array}{l}0.006^{* *} \\
{[0.003]}\end{array}$ & $\begin{array}{c}-0.002 \\
{[0.004]}\end{array}$ & & $\begin{array}{l}0.007^{* *} \\
{[0.003]}\end{array}$ & $\begin{array}{c}-0.002 \\
{[0.004]}\end{array}$ \\
\hline$\Delta \mathrm{CPI}^{\mathrm{def}}$ & & & $\begin{array}{l}-0.078 \\
{[0.338]}\end{array}$ & & & \\
\hline$\Delta P P I^{\text {def }}$ & & & & & & $\begin{array}{c}0.168^{* *} \\
{[0.064]}\end{array}$ \\
\hline$\triangle \mathrm{PP}^{\mathrm{def}}$ & & & $\begin{array}{c}0.237^{* * *} \\
{[0.054]}\end{array}$ & & & $\begin{array}{l}0.267^{* * *} \\
{[0.058]}\end{array}$ \\
\hline$\Delta E P^{\text {def }}$ & & & $\begin{array}{l}0.016^{* *} \\
{[0.007]}\end{array}$ & & & $\begin{array}{r}0.017^{* *} \\
{[0.007]}\end{array}$ \\
\hline Observations & 2,498 & 1,058 & 1,058 & 2,321 & 1,031 & 1,031 \\
\hline$R^{2}$ & 0.008 & 0.241 & 0.275 & 0.011 & 0.230 & 0.283 \\
\hline Number of economies in sample & 38 & 32 & 32 & 38 & 31 & 31 \\
\hline
\end{tabular}

(b) Less than $1 \%$

\begin{tabular}{|c|c|c|c|c|c|c|}
\hline & $(1)$ & (2) & (3) & (4) & (5) & (6) \\
\hline$\triangle \mathrm{CPI}$ & $\begin{array}{r}-0.133 \\
{[0.190]}\end{array}$ & $\begin{array}{r}-0.275 \\
{[0.257]}\end{array}$ & $\begin{array}{r}-0.254 \\
{[0.250]}\end{array}$ & & & \\
\hline$\triangle \mathrm{PPI}$ & & & & $\begin{array}{c}0.112^{* *} \\
{[0.052]}\end{array}$ & $\begin{array}{l}0.117^{* * *} \\
{[0.041]}\end{array}$ & $\begin{array}{l}0.125^{* * *} \\
{[0.042]}\end{array}$ \\
\hline$\triangle \mathrm{PP}$ & & $\begin{array}{c}0.278^{* * *} \\
{[0.037]}\end{array}$ & $\begin{array}{c}0.216^{*} \\
{[0.119]}\end{array}$ & & $\begin{array}{l}0.179^{* * *} \\
{[0.036]}\end{array}$ & $\begin{array}{l}0.130^{* * *} \\
{[0.030]}\end{array}$ \\
\hline$\triangle E P$ & & $\begin{array}{r}0.007 \\
{[0.008]}\end{array}$ & $\begin{array}{r}0.001 \\
{[0.013]}\end{array}$ & & $\begin{array}{c}-0.001 \\
{[0.004]}\end{array}$ & $\begin{array}{r}0.010 \\
{[0.013]}\end{array}$ \\
\hline$\triangle P P^{\text {def }}$ & & & $\begin{array}{r}0.114 \\
{[0.187]}\end{array}$ & & & $\begin{array}{r}0.138^{*} \\
{[0.079]}\end{array}$ \\
\hline$\Delta E P^{\text {def }}$ & & & $\begin{array}{r}0.013 \\
{[0.020]}\end{array}$ & & & $\begin{array}{r}-0.019 \\
{[0.019]}\end{array}$ \\
\hline Observations & 323 & 125 & 125 & 588 & 299 & 299 \\
\hline$R^{2}$ & 0.004 & 0.332 & 0.337 & 0.010 & 0.238 & 0.256 \\
\hline Number of economies in sample & 37 & 25 & 25 & 38 & 29 & 29 \\
\hline
\end{tabular}


Table 5 continued

(c) Less than $3 \%$

\begin{tabular}{|c|c|c|c|c|c|c|}
\hline & $(1)$ & $(2)$ & (3) & (4) & (5) & (6) \\
\hline$\triangle \mathrm{CPI}$ & $\begin{array}{r}0.114 \\
{[0.118]}\end{array}$ & $\begin{array}{r}0.181 \\
{[0.146]}\end{array}$ & $\begin{array}{r}0.156 \\
{[0.140]}\end{array}$ & & & \\
\hline$\triangle \mathrm{PPI}$ & & & & $\begin{array}{c}0.130^{* *} \\
{[0.049]}\end{array}$ & $\begin{array}{r}0.126^{* * *} \\
{[0.041]}\end{array}$ & $\begin{array}{r}0.136^{* * *} \\
{[0.041]}\end{array}$ \\
\hline$\triangle \mathrm{PP}$ & & $\begin{array}{r}0.201^{* * *} \\
{[0.019]}\end{array}$ & $\begin{array}{l}0.141^{* * *} \\
{[0.027]}\end{array}$ & & $\begin{array}{l}0.188^{* * *} \\
{[0.024]}\end{array}$ & $\begin{array}{l}0.132^{* * *} \\
{[0.024]}\end{array}$ \\
\hline$\triangle E P$ & & $\begin{array}{r}0.008^{* * * *} \\
{[0.003]}\end{array}$ & $\begin{array}{r}0.003 \\
{[0.007]}\end{array}$ & & $\begin{array}{c}0.005^{*} \\
{[0.003]}\end{array}$ & $\begin{array}{r}0.007 \\
{[0.009]}\end{array}$ \\
\hline$\Delta P P^{\text {def }}$ & & & $\begin{array}{c}0.170^{* *} \\
{[0.064]}\end{array}$ & & & $\begin{array}{c}0.174^{* *} \\
{[0.064]}\end{array}$ \\
\hline$\Delta E P^{\text {def }}$ & & & $\begin{array}{r}0.012 \\
{[0.014]}\end{array}$ & & & $\begin{array}{l}-0.004 \\
{[0.016]}\end{array}$ \\
\hline $\begin{array}{l}\text { Observations } \\
R^{2}\end{array}$ & $\begin{array}{r}955 \\
0.004\end{array}$ & $\begin{array}{r}501 \\
0.318\end{array}$ & $\begin{array}{r}501 \\
0334\end{array}$ & $\begin{array}{r}983 \\
0.014\end{array}$ & $\begin{array}{r}503 \\
0.290\end{array}$ & $\begin{array}{r}503 \\
0.310\end{array}$ \\
\hline Number of economies in sample & 38 & 29 & 29 & 38 & 31 & 31 \\
\hline
\end{tabular}

$\mathrm{CPI}=$ consumer price index, $\mathrm{PPI}=$ producer price index

Notes: The dependent variable is the log change of per capita real GDP. $\triangle \mathrm{CPI}, \triangle \mathrm{PPI}, \triangle \mathrm{PP}$ and $\triangle \mathrm{EP}$ are, respectively, the log change in the $\mathrm{CPI}$, the $\mathrm{PPI}$, property prices, and stock prices. $\triangle \mathrm{CP}^{\mathrm{def}}, \Delta \mathrm{PPI}^{\mathrm{def}}, \triangle \mathrm{PP}^{\text {def }}$, and $\triangle \mathrm{EP}^{\text {def }}$ are, respectively, the log changes interacted with a dummy variable that is equal to 1 when the respective price index declines and zero otherwise. $\left.{ }^{* * *}\right|^{* * *}$ denotes significance at the $10 / 5 / 1 \%$ level.

Numbers in brackets are cluster-robust standard errors.

Sources: Authors' calculation. CPI and PPI are from Global Financial Database, International Historical Statistics 1750-2010 and International Financial Statistics, and per capita real GDP, from the Maddison Project and World Development Indicators. Property prices are from the BIS residential property price database and the OECD analytical house price database. The stock price data are from the Global Financial Database, Bloomberg, and Shularick and Taylor (2012).

However, this negative result (negative coefficient) for price-level changes does not carry over when PPI inflation is considered, except in the limited specification where the change in PPI inflation is the sole explanatory variable. The full specification in column 6 suggests that the change in the PPI is significantly associated with output growth, in the expected way (deflation lowers growth), when we focus on periods of deflation. Changes in asset prices also matter, especially in deflationary periods, but they do not alter the foregoing finding.

When we restrict the sample so as to exclude high inflation years, as in panels $b$ and $c$ of Table 5, these conclusions come through still more clearly. The rate of inflation/deflation is strongly associated with the rate of GDP growth when inflation and deflation are measured by the PPI rather than the CPI. Asset prices also matter, but their inclusion does not modify the results.

Table 6 looks instead at peaks in the CPI and PPI, asking whether dips in one, the other or both are negatively associated with economic growth. We estimate a panel regression with country fixed effects. The dependent variable is $\left(y_{i, t+h}-y_{i, t}\right)-\left(y_{i, t}-y_{i, t-h}\right), \mathrm{h}=1, \ldots, 5$, where $y_{i, t}$ is the log level of per capita real GDP for country $i$ at $t$. $\mathrm{P}^{C P I}, \mathrm{P}^{\mathrm{PPI}}$, and $\mathrm{P}^{\mathrm{EP}}$ are, respectively, the CPI, PPI, and property price peak dummies that take the value of 1 at peaks and zero otherwise. Estimates for the full sample period are consistent with the idea that the GDP growth rate is lower after peaks using both measures of the price level. The subsample results suggest that the full sample coefficient on the CPI peak is driven primarily by the Great Depression era, with its pronounced price-level peak in 1929. In contrast, it appears that growth in the modern (post-World War II) period is lower after price-level peaks than before when we consider the PPI instead of the CPI. Again, considering the PPI does not suggest that "it is all about the Great Depression." 
Table 6: Change in Output Growth Following CPI, PPI, and Equity-Price Peaks

\begin{tabular}{|c|c|c|c|c|c|c|}
\hline & & (1) $h=1$ & (2) $h=2$ & (3) $h=3$ & (4) $h=4$ & (5) $h=5$ \\
\hline \multirow{5}{*}{ Full sample } & $P^{C P T}$ & $-0.018^{*}$ & $-0.034^{* * *}$ & $-0.053^{* *}$ & $-0.065^{* *}$ & $-0.065^{* *}$ \\
\hline & $P^{P P I}$ & -0.013 & $-0.025^{* *}$ & $-0.032^{* * *}$ & $-0.028^{* *}$ & $-0.044^{* * *}$ \\
\hline & $P^{E P}$ & $-0.008^{* * *}$ & $-0.034^{* * *}$ & $-0.058^{* * *}$ & $-0.071^{* * *}$ & $-0.080^{* * *}$ \\
\hline & $\mathrm{P}^{\mathrm{CPI}}$ alone & -0.008 & $-0.036^{* * *}$ & $-0.046^{* *}$ & $-0.052^{*}$ & $-0.055^{* *}$ \\
\hline & $\mathrm{P}^{\mathrm{PPI}}$ alone & $-0.012^{*}$ & $-0.026^{* *}$ & $-0.034^{* * *}$ & $-0.037^{* * *}$ & $-0.053^{* * *}$ \\
\hline \multirow{5}{*}{ Classical gold standard } & $P^{C P l}$ & -0.009 & -0.008 & -0.022 & -0.022 & -0.012 \\
\hline & $P^{P P I}$ & 0.014 & -0.006 & -0.006 & 0.033 & -0.004 \\
\hline & $P^{E P}$ & -0.008 & -0.027 & $-0.042^{* *}$ & $-0.055^{* *}$ & $-0.049 * *$ \\
\hline & $\mathrm{P}^{\mathrm{CPI}}$ alone & 0.004 & -0.013 & -0.015 & -0.008 & -0.006 \\
\hline & $\mathrm{P}^{\mathrm{PPI}}$ alone & 0.005 & -0.005 & -0.018 & -0.009 & $-0.026^{*}$ \\
\hline \multirow{5}{*}{ Interwar } & $\mathrm{P}^{\mathrm{CPI}}$ & $-0.038^{* * *}$ & $-0.135^{* * *}$ & $-0.181^{\text {*** }}$ & $-0.242^{* * *}$ & $-0.225^{* * *}$ \\
\hline & $P^{P P I}$ & -0.007 & -0.028 & -0.037 & $-0.099^{* *}$ & $-0.118^{* * *}$ \\
\hline & $P^{E P}$ & -0.015 & $-0.058^{* *}$ & $-0.140^{* * *}$ & $-0.191^{1 * *}$ & $-0.208^{* * *}$ \\
\hline & $\mathrm{P}^{\mathrm{CPI}}$ alone & -0.024 & $-0.110^{* * *}$ & $-0.154^{* * *}$ & $-0.213^{* * *}$ & $-0.200^{* * *}$ \\
\hline & $\mathrm{P}^{\mathrm{PPl}}$ alone & 0.004 & $-0.073^{* *}$ & $-0.106^{* *}$ & $-0.156^{* * *}$ & $-0.201^{* *}$ \\
\hline \multirow{5}{*}{ Postwar } & $\mathrm{P}^{\mathrm{CPI}}$ & -0.043 & -0.026 & -0.032 & -0.040 & -0.038 \\
\hline & $\mathrm{P}^{\mathrm{PPI}}$ & $-0.020^{* * *}$ & $-0.035^{* * *}$ & $-0.045^{* * *}$ & $-0.041^{* *}$ & -0.044 \\
\hline & $P^{E P}$ & $-0.008^{* * *}$ & $-0.032^{* * *}$ & $-0.049^{* * *}$ & $-0.055^{* * *}$ & $-0.065^{* * *}$ \\
\hline & $\mathrm{P}^{\mathrm{CPI}}$ alone & $-0.047^{*}$ & -0.029 & $-0.036^{*}$ & $-0.042^{*}$ & -0.039 \\
\hline & $\mathrm{P}^{\mathrm{PPI}}$ alone & $-0.021^{* * *}$ & $-0.034^{* * *}$ & $-0.042^{* * *}$ & $-0.038^{* *}$ & -0.041 \\
\hline
\end{tabular}

$\mathrm{CPI}=$ consumer price index, $\mathrm{PPI}=$ producer price index .

Notes: The dependent variable is $\left(y_{i, t+h}-y_{i, t}\right)-\left(y_{i, t}-y_{i, t-h}\right), \mathrm{h}=1, \ldots, 5$, where $y_{i, t}$ is the log level of per capita real GDP for country $i$ at $t$. $\mathrm{P}^{\mathrm{CPI}}, \mathrm{P}^{\mathrm{PPI}}$, and $\mathrm{P}^{\mathrm{EP}}$ are, respectively, the CPI, PPI, and property price peaks. See note to Table 1 for the definition of CPI and PPI peaks. The Property price peak is defined similarly. $\mathrm{P}^{C P \mathrm{P}}$ alone and $\mathrm{P}^{\mathrm{PPI}}$ alone present the same regression results estimated over the same time and country sample with only the CPI peaks and PPI peaks, respectively. ${ }^{* * *} /{ }^{* * *}$ denotes significance at the 10/5/1\% level. Numbers in brackets are cluster-robust standard errors.

Sources: Authors' calculation. CPI and PPI are from Global Financial Database, International Historical Statistics 1750-2010 and International Financial Statistics, and per capita real GDP, from the Maddison Project and World Development Indicators. The stock price data are from the Global Financial Database, Bloomberg, and Shularick and Taylor (2012).

Finally, Table 7 looks directly at growth in years before and after price level peaks; in addition, it interacts the dummy variable for whether a year is after a price-level peak with measures of the change in property prices and stock prices. The dependent variable is $\left(y_{i, t+5}-y_{i, t}\right)-\left(y_{i, t}-y_{i, t-5}\right)$. D is the government debt-to-GDP ratio (columns 3 and 4 ) and the private debt-to-GDP ratio (columns 5-8), where the private debt is measured by bank loans to the nonfinancial private sector. Both public and private debt ratios are detrended using a linear trend in columns 3-6. The private credit gap is detrended by using the two-sided Hodrick-Prescott filter in columns 7-8. The debt variables are interacted with the four peak dummies when used as regressors. The estimation period is limited to the modern era, reflecting our limited data on property prices. When the interaction terms are not included (columns 1 and 2), the coefficient on the CPI peak is positive but that on the PPI peak is negative. This pattern for the PPI is consistent with the idea that growth is lower after the price level peaks and goes into decline. Again we are alerted to the sensitivity of results to the particular measure of the price level considered. In addition, consistent with the argument that asset-price fluctuations also matter, growth is also significantly lower following property-price and stock-market peaks. 
Table 7: Change in 5-Year Output Growth after CPI, PPI, Property-Price, and Equity-Price Peaks (Postwar)

\begin{tabular}{|c|c|c|c|c|c|c|c|c|}
\hline & \multirow[b]{2}{*}{ (1) } & \multirow[b]{2}{*}{ (2) } & \multicolumn{2}{|c|}{ Public Debt Ratio } & \multicolumn{2}{|c|}{ Private Debt Ratio } & \multicolumn{2}{|c|}{ Private Credit Gap } \\
\hline & & & (3) & (4) & (5) & (6) & $(7)$ & (8) \\
\hline \multirow[t]{2}{*}{$\mathrm{P}^{\mathrm{CPI}}$} & $0.013^{* *}$ & & $0.054^{* * *}$ & & $0.008^{*}$ & & $0.013^{* * *}$ & \\
\hline & {$[0.006]$} & & {$[0.002]$} & & [0.004] & & {$[0.002]$} & \\
\hline \multirow[t]{2}{*}{$P^{P P I}$} & & $-0.061^{* *}$ & & $-0.060^{* *}$ & & -0.023 & & -0.053 \\
\hline & & {$[0.029]$} & & [0.027] & & [0.037] & & [0.032] \\
\hline \multirow[t]{2}{*}{$P^{P P}$} & $-0.087^{* * *}$ & $-0.088^{* * *}$ & $-0.084^{* * *}$ & $-0.085^{* * *}$ & $-0.063^{* * *}$ & $-0.063^{* * *}$ & $-0.047^{* *}$ & $-0.044^{*}$ \\
\hline & [0.021] & [0.021] & [0.022] & [0.022] & [0.022] & [0.022] & [0.023] & [0.023] \\
\hline \multirow[t]{2}{*}{$P^{E P}$} & $-0.066^{* * *}$ & $-0.068^{* * *}$ & $-0.070^{* * *}$ & $-0.070^{* * *}$ & $-0.067^{* * *}$ & $-0.066^{* * *}$ & $-0.063^{* * *}$ & $-0.063^{* * *}$ \\
\hline & [0.012] & [0.012] & [0.011] & [0.011] & [0.012] & [0.012] & [0.012] & [0.012] \\
\hline \multirow[t]{2}{*}{$D^{*} P^{C P I}$} & & & $-0.000^{* * *}$ & & 0.058 & & 0.138 & \\
\hline & & & [0.000] & & [0.039] & & {$[0.110]$} & \\
\hline \multirow[t]{2}{*}{$D^{*} P^{P P I}$} & & & & $0.001^{*}$ & & $-0.076^{* *}$ & & 0.176 \\
\hline & & & & {$[0.000]$} & & {$[0.035]$} & & {$[0.263]$} \\
\hline \multirow[t]{2}{*}{$D^{*} P^{P P}$} & & & 0.000 & 0.001 & $-0.081^{* *}$ & $-0.081^{* *}$ & $-0.329 * *$ & $-0.341^{* *}$ \\
\hline & & & {$[0.001]$} & {$[0.001]$} & [0.039] & {$[0.037]$} & {$[0.142]$} & [0.144] \\
\hline \multirow[t]{2}{*}{$D^{*} P^{E P}$} & & & $0.001^{* * *}$ & $0.001^{* * *}$ & -0.004 & -0.015 & -0.154 & -0.172 \\
\hline & & & {$[0.000]$} & {$[0.000]$} & [0.027] & {$[0.027]$} & [0.149] & [0.154] \\
\hline Observations & 932 & 909 & 899 & 891 & 930 & 907 & 930 & 907 \\
\hline $\mathrm{R}^{2}$ & 0.055 & 0.061 & 0.066 & 0.070 & 0.059 & 0.066 & 0.063 & 0.070 \\
\hline Number of groups & 30 & 30 & 29 & 29 & 30 & 30 & 30 & 30 \\
\hline
\end{tabular}

$\mathrm{CPI}=$ consumer price index, $\mathrm{PPI}=$ producer price index.

Notes: The dependent variable is $\left(y_{i, t+5}-y_{i, t}\right)-\left(y_{i, t}-y_{i, t-5}\right)$, where $y_{i, t}$ is the log level of per capita real GDP for country $i$ at $t . \mathrm{P}^{\mathrm{CPI}}, \mathrm{P}^{\mathrm{PPI}}, \mathrm{P}^{\mathrm{PP}}$, and $\mathrm{P}^{\mathrm{EP}}$ are, respectively, the CPI, PPI, property price, and stock price peak dummies that take one at peaks and zero otherwise. See note to Table 1 for the definition of CPI and PPI peaks. The property price and stock price peaks are defined similarly. $D$ is the government debt-to-GDP ratio (columns 3-4) and the private debt-to-GDP ratio (columns 5-8), where the private debt is measured by bank loans to the nonfinancial private sector. Both public and private debt ratios are detrended using a linear trend in columns 3-6. The private credit gap is detrended by using the two-sided Hodrick-Prescott filter in columns 7-8. The debt variables are interacted with the four peak dummies when used as regressors

Sources: Authors' calculation. CPI and PPI are from Global Financial Database, International Historical Statistics 1750-2010 and International Financial Statistics, and per capita real GDP, from the Maddison Project and World Development Indicators. Property prices are from the BIS residential property price database and the OECD analytical house price database. The stock price data are from the Global Financial Database, Bloomberg, and Shularick and Taylor (2012). 
In columns 3-8, we interact these dummy variables for peaks with various measures of indebtedness as a more direct test of the debt-deflation hypothesis (although we would emphasize, echoing the discussion in this paper's introduction, that it is not only through debt deflation that falls in the price level can, in principle, be damaging). ${ }^{14}$ When we distinguish public from private debt, the interaction term with the peak in the CPI is negative and significant in the case of public debt, but the coefficient on interaction term with the peak in the PPI is negative and significant in the case of private debt. We also find that the coefficient on the interaction term of the private debt with the peak in property price is negative and significant, suggesting that private debt makes property price deflations more costly. This is again consistent with the findings of Borio et al. (2015).

\section{WHAT ELSE IS SPECIAL ABOUT THE POST-WORLD WAR II PERIOD?}

Long historical time series as analyzed here have the advantage of highlighting what if anything is distinctive about the deflation-growth nexus in the modern world. But the post-World War II period (which is what most previous analysts have meant by "the modern world" in practice) is also special, potentially, in other regards. Compared to the classical gold standard and interwar eras that preceded this modern period, modern economic growth had preceded for longer in some parts of the world. This made for different initial conditions-different levels of per capita GDP-which created scope for different rates of catch-up growth. As is well known, not only do late-developing catch-up economies grow relatively fast (as a matter of definition), but they also tend to experience relative high rates of inflation (due to the operation of the Balassa-Samuelson effect). Thus, not controlling for these initial conditions may have implications for the observed correlation between deflation and growth in general, and in the post-World War II period in particular.

In addition, the immediate aftermath of World War II was marked by exceptional swings between inflation and deflation (in the US, the rate of CPI inflation swung from $1.4 \%$ in 1947 to $-1.2 \%$ in 1949 and $7.9 \%$ in 1951). Output recovered strongly not so much because of any influence of inflation or deflation on expectations but because of the removal of wartime price controls, the elimination of postwar production ceilings on key industries (as in Germany) and the repair of wartime damage.

Table 8 shows how the results change when we control for these effects, eliminating the subperiod 1946-1949 and controlling for per capita GDP. Table 8.a presents the results when the growth rate of real GDP per capita for country $i$ at time $t, y_{i t}$, is regressed on a low CPI (PPI) inflation dummy, $d_{i t}^{L}$, and a high CPI (PPI) inflation dummy, $d_{i t}^{H}$.

$$
y_{i t}=\beta_{0}+\gamma_{1} d_{i t}^{L}+\gamma_{2} d_{i t}^{H}+\varepsilon_{i t}
$$

The constant term, $\beta_{0}$, in these regressions is the average rate of growth of per capita GDP in deflation years, whereas the rate of growth in years of low (high) inflation is the sum of the constant, $\beta_{0}$, and the coefficient on the low (high) inflation dummy variable, $d_{i t}^{L}\left(d_{i t}^{H}\right){ }^{15}$ We report regression results based on pooled ordinary least squares and panel estimates with fixed effects.

14 Fisher (1933) developed a debt-deflation theory of Great Depression where a fall in the level of prices decreases net worth of business, by increasing the value of nominal debts, causing decreases in investment. While it would be desirable to investigate the role of debt deflation based on its impact on investment, since investment data for the historical period are not generally available, we use the growth rate of per capita real GDP as a dependent variable. We believe that if debt deflation decreases investment, it will also decrease the growth rate of GDP as well.

15 This interpretation is possible since we adjust $y_{i t}$ by subtracting from it the mean growth rate of per capita real GDP in deflation years. 
Table 8: CPI and PPI Deflations and Average Real GDP Growth Rate

(a) Current income not controlled

\begin{tabular}{|c|c|c|c|c|c|c|c|c|c|c|c|c|}
\hline & \multicolumn{4}{|c|}{ Full Sample } & \multicolumn{4}{|c|}{ Classical Gold Standard } & \multicolumn{4}{|c|}{ Interwar } \\
\hline & \multicolumn{2}{|c|}{ CPI } & \multicolumn{2}{|c|}{ PPI } & \multicolumn{2}{|c|}{$\mathrm{CPI}$} & \multicolumn{2}{|c|}{ PPI } & \multicolumn{2}{|c|}{ CPI } & \multicolumn{2}{|c|}{ PPI } \\
\hline & Pooled & $\begin{array}{l}\text { Fixed } \\
\text { Effect }\end{array}$ & Pooling & $\begin{array}{l}\text { Fixed } \\
\text { Effect }\end{array}$ & Pooling & $\begin{array}{l}\text { Fixed } \\
\text { Effect }\end{array}$ & Pooling & $\begin{array}{l}\text { Fixed } \\
\text { Effect }\end{array}$ & Pooling & $\begin{array}{l}\text { Fixed } \\
\text { Effect }\end{array}$ & Pooling & $\begin{array}{l}\text { Fixed } \\
\text { Effect }\end{array}$ \\
\hline \multirow{2}{*}{ Constant } & $1.17^{* * *}$ & $1.23^{* * *}$ & $1.40^{* * *}$ & $1.38^{* * *}$ & $1.17^{* * *}$ & $1.20^{* * *}$ & $1.29^{* * *}$ & $1.28^{* * *}$ & 0.36 & 0.24 & 0.42 & 0.27 \\
\hline & {$[0.160]$} & {$[0.226]$} & {$[0.130]$} & {$[0.159]$} & {$[0.273]$} & [0.299] & {$[0.219]$} & {$[0.281]$} & {$[0.360]$} & {$[0.353]$} & {$[0.389]$} & {$[0.295]$} \\
\hline \multirow{2}{*}{ Low inflation } & $1.57^{* * *}$ & $1.49^{* * *}$ & $1.35^{* * *}$ & $1.37^{* * *}$ & 0.43 & 0.37 & $0.57^{*}$ & 0.59 & $3.34^{* * *}$ & $3.58^{* * *}$ & $3.29^{* * *}$ & $3.72^{* * *}$ \\
\hline & {$[0.181]$} & {$[0.279]$} & {$[0.161]$} & {$[0.207]$} & {$[0.371]$} & {$[0.472]$} & {$[0.308]$} & {$[0.505]$} & {$[0.533]$} & {$[0.709]$} & {$[0.627]$} & {$[0.734]$} \\
\hline \multirow{2}{*}{ High inflation } & $1.14^{* * *}$ & $1.07^{* * *}$ & $1.02^{* * *}$ & $1.08^{* * *}$ & 0.00 & -0.11 & 0.22 & 0.14 & $2.67^{* * *}$ & $2.90^{* * *}$ & $4.24^{* * *}$ & $4.27^{* * *}$ \\
\hline & {$[0.226]$} & {$[0.375]$} & {$[0.201]$} & {$[0.359]$} & {$[0.912]$} & {$[2.084]$} & {$[0.718]$} & [1.336] & [0.824] & {$[0.962]$} & [0.945] & [0.893] \\
\hline Observations & 3,583 & 3,583 & 3,333 & 3,333 & 603 & 603 & 601 & 601 & 511 & 511 & 440 & 440 \\
\hline R-squared & 0.020 & 0.019 & 0.021 & 0.022 & 0.002 & 0.002 & 0.006 & 0.006 & 0.076 & 0.085 & 0.080 & 0.096 \\
\hline
\end{tabular}

\begin{tabular}{|c|c|c|c|c|c|c|c|c|}
\hline & \multicolumn{8}{|c|}{ Postwar } \\
\hline & \multicolumn{4}{|c|}{$\mathrm{CPI}$} & \multicolumn{4}{|c|}{ PPI } \\
\hline & \multicolumn{2}{|c|}{ Pooling } & \multicolumn{2}{|c|}{ Fixed Effect } & \multicolumn{2}{|c|}{ Pooling } & \multicolumn{2}{|c|}{ Fixed Effect } \\
\hline & $\begin{array}{l}\text { Since } \\
1946\end{array}$ & $\begin{array}{l}\text { Since } \\
1950\end{array}$ & $\begin{array}{l}\text { Since } \\
1946\end{array}$ & $\begin{array}{l}\text { Since } \\
1950\end{array}$ & $\begin{array}{l}\text { Since } \\
1946\end{array}$ & $\begin{array}{l}\text { Since } \\
1950\end{array}$ & $\begin{array}{l}\text { Since } \\
1946\end{array}$ & $\begin{array}{l}\text { Since } \\
1950\end{array}$ \\
\hline \multirow{2}{*}{ Constant } & $2.55^{* * *}$ & $2.00^{* * *}$ & $2.05^{* * *}$ & $1.39^{* * *}$ & $2.10^{* * *}$ & $2.08^{* * *}$ & $1.80^{* * *}$ & $1.82^{* * *}$ \\
\hline & [0.294] & [0.298] & [0.498] & [0.397] & {$[0.173]$} & [0.169] & [0.169] & {$[0.170]$} \\
\hline \multirow{2}{*}{ Low inflation } & 0.27 & $0.81^{* * *}$ & 0.76 & $1.44^{* * *}$ & $0.74^{* * *}$ & $0.71^{* * *}$ & $1.06^{* * *}$ & $1.01^{* * *}$ \\
\hline & [0.306] & [0.309] & [0.543] & [0.425] & [0.197] & [0.192] & [0.204] & {$[0.197]$} \\
\hline \multirow{2}{*}{ High inflation } & -0.27 & 0.05 & 0.40 & $0.76^{*}$ & 0.18 & 0.01 & $0.65^{* *}$ & 0.36 \\
\hline & [0.329] & {$[0.331]$} & [0.532] & [0.438] & {$[0.223]$} & {$[0.220]$} & {$[0.283]$} & {$[0.278]$} \\
\hline Observations & 2,469 & 2,345 & 2,469 & 2,345 & 2,292 & 2,177 & 2,292 & 2,177 \\
\hline R-squared & 0.004 & 0.010 & 0.004 & 0.014 & 0.009 & 0.011 & 0.013 & 0.016 \\
\hline
\end{tabular}


Table 8 continued

(b) Current income controlled I

\begin{tabular}{|c|c|c|c|c|c|c|c|c|c|c|c|c|}
\hline & \multicolumn{4}{|c|}{ Full Sample } & \multicolumn{4}{|c|}{ Classical Gold Standard } & \multicolumn{4}{|c|}{ Interwar } \\
\hline & \multicolumn{2}{|c|}{$\mathrm{CPI}$} & \multicolumn{2}{|c|}{ PPI } & \multicolumn{2}{|c|}{$\mathrm{CPI}$} & \multicolumn{2}{|c|}{ PPI } & \multicolumn{2}{|c|}{$\mathrm{CPI}$} & \multicolumn{2}{|c|}{ PPI } \\
\hline & Pooling & $\begin{array}{l}\text { Fixed } \\
\text { Effect }\end{array}$ & Pooling & $\begin{array}{l}\text { Fixed } \\
\text { Effect }\end{array}$ & Pooling & $\begin{array}{l}\text { Fixed } \\
\text { Effect }\end{array}$ & Pooling & $\begin{array}{l}\text { Fixed } \\
\text { Effect }\end{array}$ & Pooling & $\begin{array}{l}\text { Fixed } \\
\text { Effect }\end{array}$ & Pooling & $\begin{array}{l}\text { Fixed } \\
\text { Effect }\end{array}$ \\
\hline \multirow{2}{*}{ Constant } & $1.17^{* * *}$ & $1.22^{* * *}$ & $1.41^{* * *}$ & $1.36^{* * *}$ & $1.17^{* * *}$ & $1.24^{* * *}$ & $1.29^{* * *}$ & $1.36^{* * *}$ & 0.36 & 0.54 & 0.42 & 0.41 \\
\hline & [0.159] & [0.227] & [0.130] & [0.158] & {$[0.272]$} & [0.270] & {$[0.219]$} & [0.269] & {$[0.360]$} & {$[0.370]$} & [0.389] & [0.355] \\
\hline \multirow{2}{*}{ Low inflation } & $1.90^{* * *}$ & $1.73^{* * *}$ & $1.44^{* * *}$ & $1.49^{* * *}$ & 0.37 & 0.02 & $0.54^{*}$ & 0.31 & $3.35^{* * *}$ & $3.14^{* * *}$ & $3.30^{* * *}$ & $3.59^{* * *}$ \\
\hline & [0.193] & [0.330] & [0.163] & {$[0.212]$} & {$[0.372]$} & [0.440] & [0.308] & [0.483] & [0.533] & {$[0.708]$} & [0.628] & [0.773] \\
\hline \multirow{2}{*}{ High inflation } & $1.30^{* * *}$ & $1.26^{* * *}$ & $1.02^{* * *}$ & $1.17^{* * *}$ & 0.23 & 0.02 & 0.32 & 0.12 & $2.61^{* * *}$ & $3.25^{* * *}$ & $4.14^{* * *}$ & $4.40^{* * *}$ \\
\hline & {$[0.228]$} & [0.399] & {$[0.201]$} & [0.346] & {$[0.921]$} & [2.100] & {$[0.719]$} & {$[1.270]$} & [0.829] & [0.989] & [0.960] & [0.864] \\
\hline \multirow{2}{*}{ Per capita GDP } & $-0.41^{* * *}$ & $-0.29^{* *}$ & $-0.25^{* * *}$ & $-0.28^{* *}$ & 0.67 & $4.36^{* * *}$ & $0.51^{*}$ & $2.63^{* * *}$ & -0.26 & $8.51^{* * *}$ & -0.36 & 4.34 \\
\hline & {$[0.084]$} & [0.124] & {$[0.079]$} & {$[0.105]$} & {$[0.412]$} & [1.318] & {$[0.286]$} & {$[0.372]$} & {$[0.435]$} & {$[2.357]$} & [0.586] & [3.546] \\
\hline Observations & 3,583 & 3,583 & 3,333 & 3,333 & 603 & 603 & 601 & 601 & 511 & 511 & 440 & 440 \\
\hline R-squared & 0.027 & 0.022 & 0.024 & 0.025 & 0.007 & 0.029 & 0.011 & 0.022 & 0.076 & 0.114 & 0.081 & 0.106 \\
\hline
\end{tabular}

\begin{tabular}{|c|c|c|c|c|c|c|c|c|}
\hline & \multicolumn{8}{|c|}{ Postwar } \\
\hline & \multicolumn{4}{|c|}{$\mathrm{CPI}$} & \multicolumn{4}{|c|}{ PPI } \\
\hline & \multicolumn{2}{|c|}{ Pooling Regression } & \multicolumn{2}{|c|}{ Fixed Effect } & \multicolumn{2}{|c|}{ Pooling Regression } & \multicolumn{2}{|c|}{ Fixed Effect } \\
\hline & $\begin{array}{l}\text { Since } \\
1946\end{array}$ & $\begin{array}{l}\text { Since } \\
1950\end{array}$ & $\begin{array}{l}\text { Since } \\
1946\end{array}$ & $\begin{array}{l}\text { Since } \\
1950\end{array}$ & $\begin{array}{l}\text { Since } \\
1946\end{array}$ & $\begin{array}{l}\text { Since } \\
1950 \\
\end{array}$ & $\begin{array}{l}\text { Since } \\
1946\end{array}$ & $\begin{array}{l}\text { Since } \\
1950\end{array}$ \\
\hline \multirow{2}{*}{ Constant } & $2.55^{* * *}$ & $2.08^{* * *}$ & $2.16^{* * *}$ & $1.61^{* * *}$ & $2.10^{* * *}$ & $2.11^{* * *}$ & $1.59^{* * *}$ & $1.66^{* * *}$ \\
\hline & {$[0.288]$} & [0.292] & {$[0.478]$} & [0.398] & {$[0.170]$} & [0.166] & {$[0.171]$} & {$[0.174]$} \\
\hline \multirow{2}{*}{ Low inflation } & $0.80^{* * *}$ & $1.27^{* * *}$ & $1.28^{* *}$ & $1.80^{* * *}$ & $0.68^{* * *}$ & $0.65^{* * *}$ & $1.06^{* * *}$ & $1.01^{* * *}$ \\
\hline & {$[0.304]$} & [0.306] & [0.485] & [0.415] & {$[0.193]$} & [0.188] & [0.197] & [0.194] \\
\hline \multirow{2}{*}{ High inflation } & -0.28 & -0.00 & 0.57 & $0.84^{*}$ & $-0.40^{*}$ & $-0.54^{* *}$ & 0.31 & 0.12 \\
\hline & {$[0.322]$} & [0.324] & [0.486] & {$[0.415]$} & {$[0.227]$} & {$[0.224]$} & [0.252] & [0.267] \\
\hline \multirow{2}{*}{ Per capita GDP } & $-0.95^{* * *}$ & $-0.92^{* * *}$ & $-1.34^{* * *}$ & $-1.16^{* * *}$ & $-0.92^{* * *}$ & $-0.88^{* * *}$ & $-1.49^{* * *}$ & $-1.37^{* * *}$ \\
\hline & {$[0.093]$} & {$[0.091]$} & [0.305] & {$[0.268]$} & {$[0.096]$} & {$[0.096]$} & {$[0.311]$} & [0.297] \\
\hline Observations & 2,469 & 2,345 & 2,469 & 2,345 & 2,292 & 2,177 & 2,292 & 2,177 \\
\hline R-squared & 0.045 & 0.052 & 0.049 & 0.048 & 0.047 & 0.048 & 0.066 & 0.059 \\
\hline
\end{tabular}

continued on next page 
Table 8 continued

(c) Current income controlled II

\begin{tabular}{|c|c|c|c|c|c|c|c|c|c|c|c|c|}
\hline & \multicolumn{4}{|c|}{ Full Sample } & \multicolumn{4}{|c|}{ Classical Gold Standard } & \multicolumn{4}{|c|}{ Interwar } \\
\hline & \multicolumn{2}{|c|}{ CPI } & \multicolumn{2}{|c|}{ PPI } & \multicolumn{2}{|c|}{ CPI } & \multicolumn{2}{|c|}{ PPI } & \multicolumn{2}{|c|}{$\mathrm{CPI}$} & \multicolumn{2}{|c|}{ PPI } \\
\hline & Pooling & $\begin{array}{l}\text { Fixed } \\
\text { Effect }\end{array}$ & Pooling & $\begin{array}{l}\text { Fixed } \\
\text { Effect }\end{array}$ & Pooling & $\begin{array}{l}\text { Fixed } \\
\text { Effect }\end{array}$ & Pooling & $\begin{array}{l}\text { Fixed } \\
\text { Effect }\end{array}$ & Pooling & $\begin{array}{l}\text { Fixed } \\
\text { Effect }\end{array}$ & Pooling & $\begin{array}{l}\text { Fixed } \\
\text { Effect }\end{array}$ \\
\hline Conctant & $1.17^{* * *}$ & $1.22^{* * *}$ & $1.40^{* * *}$ & $1.35^{* * *}$ & $1.17^{* * *}$ & $1.25^{* * *}$ & $1.29^{* * *}$ & $1.36^{* * *}$ & 0.36 & 0.54 & 0.42 & 0.4 \\
\hline Comistaint & [0.159] & [0.225] & [0.130] & [0.159] & {$[0.272]$} & [0.249] & [0.219] & {$[0.261]$} & [0.358] & [0.345] & [0.389] & {$[0.359]$} \\
\hline I ow inflation & $1.84^{* * *}$ & $1.70^{* * *}$ & $1.42^{* * *}$ & $1.48^{* * *}$ & 0.41 & 0.06 & $0.54^{*}$ & 0.32 & $3.34^{* * *}$ & $3.12^{* * *}$ & $3.28^{* * *}$ & $3.58^{* * *}$ \\
\hline Low intidion & [0.197] & [0.327] & [0.166] & [0.229] & [0.374] & [0.430] & [0.308] & [0.480] & [0.529] & [0.694] & [0.629] & {$[0.777]$} \\
\hline High & $1.45^{* * *}$ & $1.30^{* *}$ & $1.04^{* * *}$ & $1.18^{* * *}$ & 0.14 & -0.06 & 0.72 & 0.60 & $3.31^{* * *}$ & $4.05^{* * *}$ & $3.93^{* * *}$ & $4.39^{* * *}$ \\
\hline inflation & {$[0.246]$} & [0.489] & {$[0.201]$} & [0.353] & [1.029] & [1.441] & [0.755] & {$[1.272]$} & {$[0.875]$} & {$[0.846]$} & [1.045] & {$[0.836]$} \\
\hline Per capita & $-0.50^{* *}$ & -0.44 & -0.13 & $-0.26^{*}$ & $1.22^{*}$ & $5.56^{* * *}$ & 0.27 & $2.44^{* * *}$ & $-1.37^{* *}$ & $7.49^{* * *}$ & -0.57 & 4.30 \\
\hline GDP & [0.220] & [0.289] & {$[0.138]$} & [0.147] & [0.648] & [1.394] & [0.442] & {$[0.645]$} & [0.626] & {$[2.173]$} & [0.772] & {$[3.263]$} \\
\hline Per capita & 0.17 & 0.19 & -0.06 & 0.03 & -0.95 & $-1.70^{*}$ & 0.22 & 0.05 & $1.69^{*}$ & 1.35 & 1.01 & 0.17 \\
\hline GDP * Low & [0.241] & [0.304] & [0.174] & [0.183] & [0.867] & {$[0.890]$} & [0.592] & [0.861] & [0.901] & [1.243] & [1.348] & {$[1.335]$} \\
\hline Per capita & -0.26 & 0.03 & $-0.66^{* *}$ & -0.32 & -0.81 & -1.18 & $2.24^{*}$ & 2.47 & $4.62^{* * *}$ & $4.74^{* *}$ & -0.54 & 0.02 \\
\hline GDP* High & {$[0.326]$} & [0.507] & {$[0.264]$} & {$[0.269]$} & {$[1.563]$} & {$[2.863]$} & [1.281] & {$[1.636]$} & {$[1.668]$} & {$[2.294]$} & {$[1.754]$} & {$[1.825]$} \\
\hline Observations & 3,583 & 3,583 & 3,333 & 3,333 & 603 & 603 & 601 & 601 & 511 & 511 & 440 & 440 \\
\hline R-squared & 0.028 & 0.022 & 0.026 & 0.025 & 0.009 & 0.035 & 0.016 & 0.028 & 0.092 & 0.128 & 0.083 & 0.106 \\
\hline
\end{tabular}

\begin{tabular}{|c|c|c|c|c|c|c|c|c|}
\hline & \multicolumn{8}{|c|}{ Postwar } \\
\hline & \multicolumn{4}{|c|}{$\mathrm{CPI}$} & \multicolumn{4}{|c|}{ PPI } \\
\hline & \multicolumn{2}{|c|}{ Pooling Regression } & \multicolumn{2}{|c|}{ Fixed Effect } & \multicolumn{2}{|c|}{ Pooling Regression } & \multicolumn{2}{|c|}{ Fixed Effect } \\
\hline & $\begin{array}{l}\text { Since } \\
1946\end{array}$ & $\begin{array}{l}\text { Since } \\
1950\end{array}$ & $\begin{array}{l}\text { Since } \\
1946\end{array}$ & $\begin{array}{l}\text { Since } \\
1950\end{array}$ & $\begin{array}{l}\text { Since } \\
1946\end{array}$ & $\begin{array}{l}\text { Since } \\
1950\end{array}$ & $\begin{array}{l}\text { Since } \\
1946\end{array}$ & $\begin{array}{l}\text { Since } \\
1950\end{array}$ \\
\hline \multirow{2}{*}{ Constant } & $2.55^{* * *}$ & $2.11^{* * *}$ & $2.15^{* * *}$ & $1.64^{* * *}$ & $2.10^{* * *}$ & $2.13^{* * *}$ & $1.59^{* * *}$ & $1.69^{* * *}$ \\
\hline & [0.287] & [0.292] & {$[0.464]$} & [0.396] & [0.169] & [0.165] & [0.156] & {$[0.162]$} \\
\hline \multirow{2}{*}{ Low inflation } & $0.71^{* *}$ & $1.21^{* * *}$ & $1.23^{* *}$ & $1.75^{* * *}$ & $0.70^{* * *}$ & $0.63^{* * *}$ & $1.07^{* * *}$ & $0.99^{* * *}$ \\
\hline & [0.305] & [0.309] & {$[0.455]$} & {$[0.400]$} & [0.193] & [0.188] & {$[0.184]$} & {$[0.185]$} \\
\hline \multirow{2}{*}{ High inflation } & -0.28 & -0.02 & 0.57 & $0.79^{*}$ & -0.36 & $-0.42^{*}$ & $0.49^{*}$ & 0.35 \\
\hline & [0.322] & {$[0.325]$} & {$[0.462]$} & {$[0.407]$} & {$[0.259]$} & {$[0.253]$} & [0.258] & {$[0.276]$} \\
\hline \multirow{2}{*}{ Per capita GDP } & $-1.51^{* * *}$ & $-1.23^{* * *}$ & $-1.95^{* * *}$ & $-1.55^{* * *}$ & $-1.46^{* * *}$ & $-1.48^{* * *}$ & $-1.95^{* * *}$ & $-1.88^{* * *}$ \\
\hline & [0.277] & {$[0.276]$} & {$[0.444]$} & [0.377] & [0.202] & {$[0.201]$} & {$[0.356]$} & {$[0.346]$} \\
\hline Per capita GDP * & $0.70^{* *}$ & 0.37 & $0.73^{*}$ & 0.43 & $0.73^{* * *}$ & $0.76^{* * *}$ & $0.58^{* * *}$ & $0.63^{* * *}$ \\
\hline Low & [0.297] & [0.295] & [0.379] & [0.348] & [0.237] & [0.236] & [0.205] & {$[0.217]$} \\
\hline Per capita GDP* & 0.23 & 0.22 & 0.55 & 0.59 & $0.61^{* *}$ & $0.85^{* * *}$ & $0.78^{* *}$ & $1.01^{* * *}$ \\
\hline High & [0.366] & [0.365] & {$[0.473]$} & {$[0.391]$} & [0.300] & [0.303] & [0.289] & {$[0.333]$} \\
\hline Observations & 2,469 & 2,345 & 2,469 & 2,345 & 2,292 & 2,177 & 2,292 & 2,177 \\
\hline R-squared & 0.048 & 0.052 & 0.051 & 0.050 & 0.051 & 0.053 & 0.069 & 0.064 \\
\hline
\end{tabular}

$\mathrm{CPI}=$ consumer price index, $\mathrm{GDP}=$ gross domestic price, $\mathrm{PPI}=$ producer price index.

Notes: The dependent variable is the log change of per capita real GDP. The regressors are low-inflation, high-inflation dummy variables and log per capita real GDP. The low-inflation dummy takes 1 if the respective price inflation is higher than $0 \%$ and less than $10 \%$, and zero otherwise. The high-inflation dummy takes 1 when the respective inflation is higher than $10 \%$ and less than $100 \%$, and zero otherwise. Numbers in brackets are cluster-robust standard errors and $*^{* * * * *}$ denotes significance at the 10/5/1\% level.

Sources: Authors' calculation. CPI and PPI are from Global Financial Database, International Historical Statistics 1750-2010 and International Financial Statistics, and per capita real GDP, from the Maddison Project and World Development Indicators. 
The pooled ordinary least squares estimation results yield identical results to those reported in Table 3. In the first column, for example, a constant term is estimated to be 1.17, which is exactly the same as the average growth rate in deflation years for the full sample reported in Table 3 . We can also retrieve the average growth rate in low inflation years by adding the estimated coefficient of the low inflation dummy, 1.57 , to $1.17(=2.74)$. Similarly, the average growth rate in high inflation years is obtained by adding the estimated coefficient of the high inflation dummy, 1.17, to $1.17(=2.31)$. Note that, for the postwar period, the estimated coefficient of the low inflation dummy is 0.27 (in pooled regression) or 0.76 (in panel regression) and is not statistically significant, which suggests that the average growth rate in low CPI inflation years is not significantly different from that in CPI deflation years. However, if we estimate the same equation using data since 1950, the estimated coefficient of the low inflation dummy is 0.81 (in pooled regression) or 1.44 (in panel regression) and it is statistically significant at the $1 \%$ level. Hence the average growth rate in CPI deflation years is significantly lower than that in low-inflation years if we eliminate the 1946-1949 period. The PPI results, however, are not sensitive to the elimination of the subperiod 1946-1949. The coefficient of the low inflation dummy is always positive and statistically significant at conventional confidence levels.

In Table 8.b and Table 8.c, we control for per capita GDP, by adding log per capita GDP, $p c G D P_{i t}$, as an additional regressor. In Table 8.b, we report estimation results where per capita GDP is simply added as follows:

$$
y_{i t}=\beta_{0}+\gamma_{1} d_{i t}^{L}+\gamma_{2} d_{i t}^{H}+\beta_{1} p c G D P_{i t}+\varepsilon_{i t}
$$

In Table 8.c, we also allow the coefficient of $p c G D P_{i t}$ to differ across deflation, low-inflation and high-inflation years as follows:

$$
y_{i t}=\beta_{0}+\gamma_{1} d_{i t}^{L}+\gamma_{2} d_{i t}^{H}+\left(\beta_{1}+\beta_{2} d_{i t}^{L}+\beta_{3} d_{i t}^{H}\right) p c G D P_{i t}+\varepsilon_{i t}
$$

In both Table 8.b and Table 8.c, per capita GDP registers significantly, with the expected negative sign (low per capita income countries with scope for catch-up grow faster, other things equal) in all the full sample regressions and the vast majority of subperiod regressions. Now for the postWorld War II period, we find significantly slower growth in periods of deflation than in periods of low inflation: the coefficient of low inflation dummy is positive and statistically significant for both CPI and $\mathrm{PPI}$. This is true in both the pooled regressions and in the regressions including fixed effects. It is true, so long as we include per capita GDP as a control, whether or not the sample includes 1946-1949, although the difference is larger when we exclude the first four postwar years.

In Figure 1, we plot the growth rate of real GDP per capita against per capita GDP, denoting red dots as CPI low inflation years and blue dots as CPI deflation years. The fitted lines are derived from Table 8.b where the coefficient of per capita GDP is assumed to be the same across CPI deflation and CPI low inflation years. Generally, blue dots are located lower, which explains why the fitted line for deflation years is located below the red line. However, the variance is larger for blue dots, indicating that the real GDP growth rate is more diverse in deflation years. 


\section{Figure 1: Current Income and Average Log of Real GDP Growth Rate during Deflation and Low Inflation: The Same Slope I}

(a) Full sample

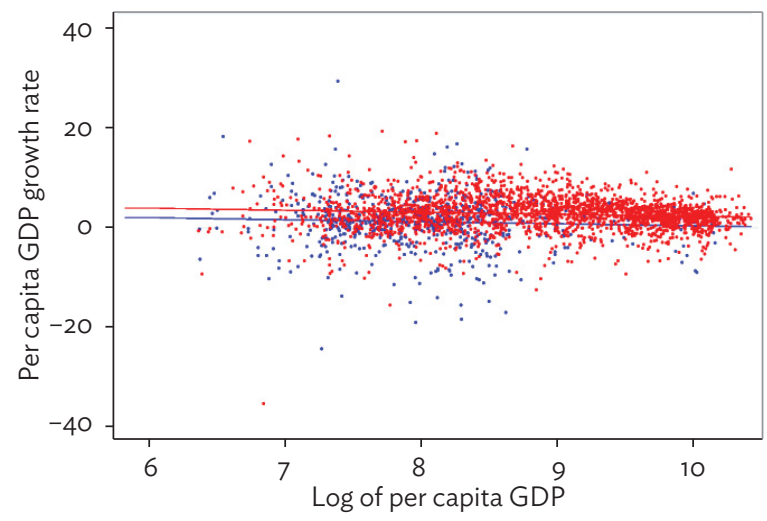

(c) Interwar

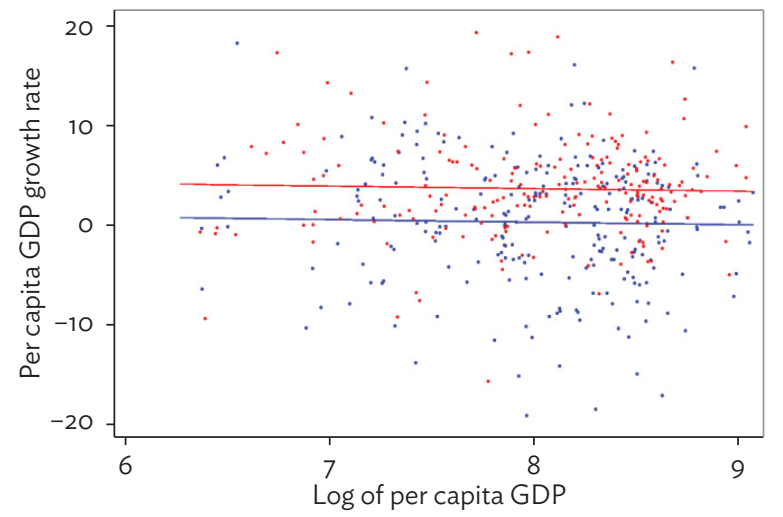

(b) Classical gold standard

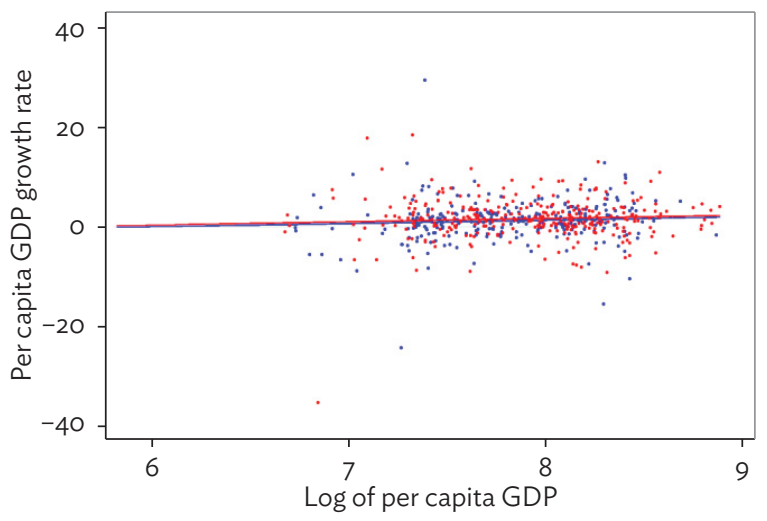

(d) Postwar

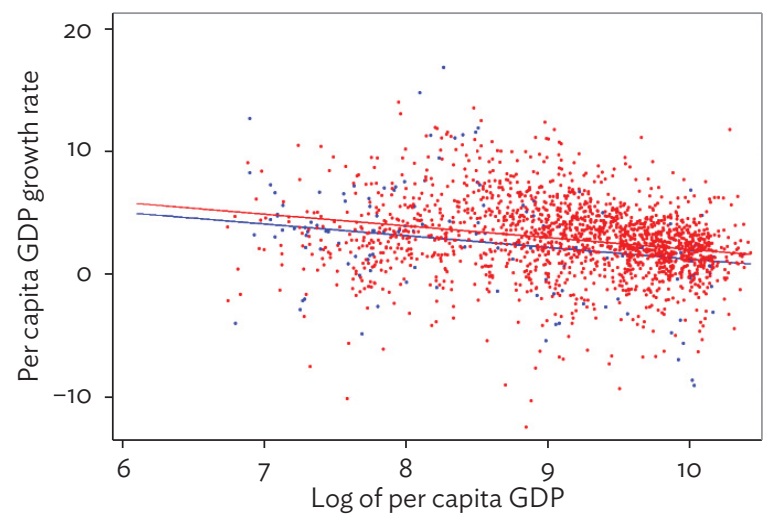

- Deflation — Fitted values • Low inflation — Fitted values

GDP = gross domestic product.

Notes: We plot the growth rate of real GDP per capita against per capita GDP, denoting red dots as CPI low inflation years and blue dots as CPI deflation years. The fitted lines are derived from Table 8.b where the coefficient of per capita GDP is assumed to be the same across CPI deflation and CPI low inflation years.

Source: Authors' calculations.

Figure 2 is the same as Figure 1 except that the coefficient of per capita GDP (the slope) is allowed to differ across CPI deflation and CPI low-inflation years. Interestingly, the gap between the two fitted lines of deflation and low-inflation years gets wider as per capita GDP increases. This indicates that CPI deflation can be worse in high-income countries than in low-income countries. 


\section{Figure 2: Current Income and Average Log of Real GDP Growth Rate during Deflation and Low Inflation: Different Slopes}
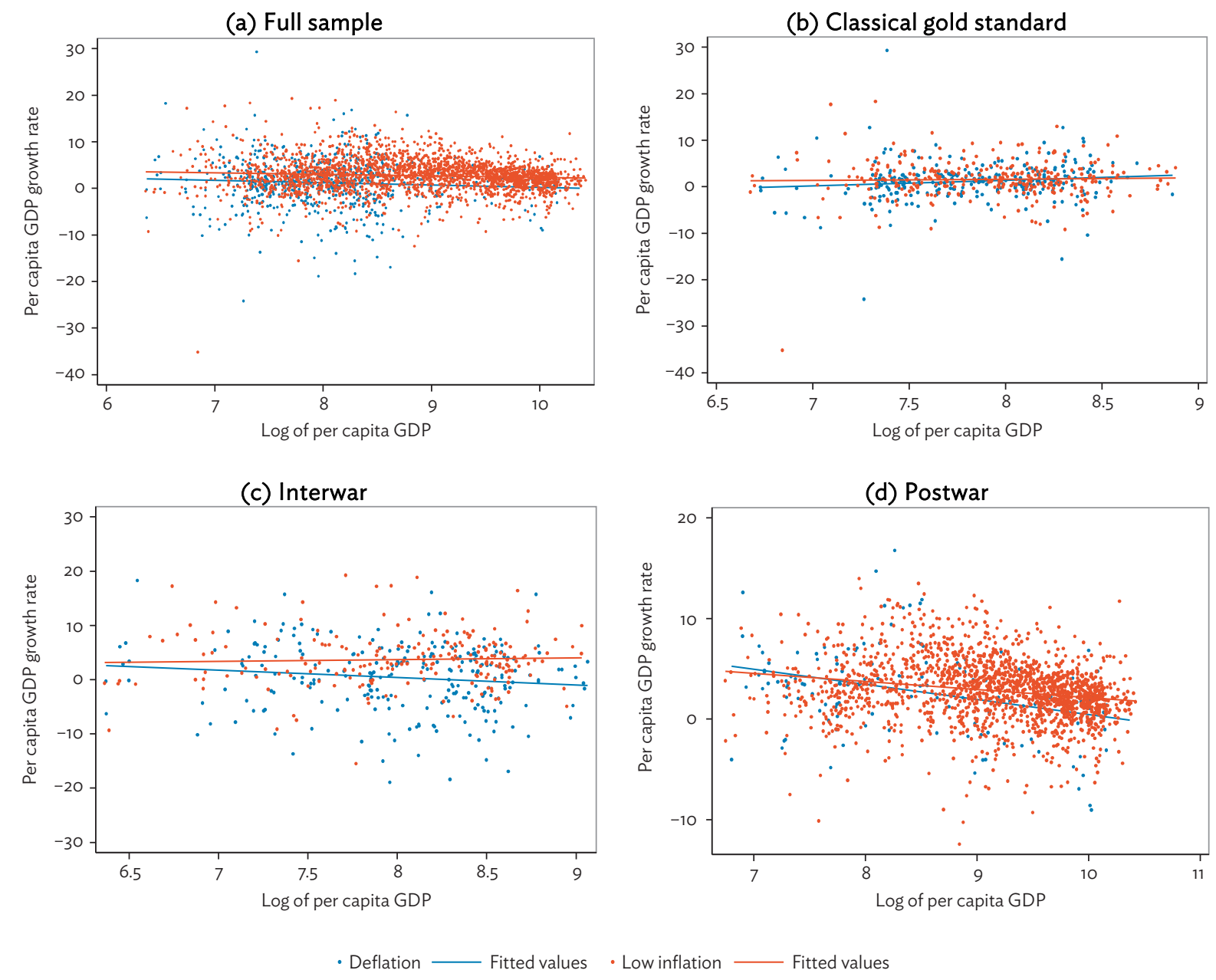

GDP = gross domestic product.

Notes: We plot the growth rate of real GDP per capita against per capita GDP, denoting red dots as CPI low inflation years and blue dots as CPI deflation years. The fitted lines are derived from Table 8.c where the coefficient of per capita GDP (the slope) is allowed to differ across CPI deflation and CPI low-inflation years.

Source: Authors' calculations.

\section{TENTATIVE CONCLUSIONS}

To the question posed in the title of this paper (can the danger of deflation be dismissed?), our answer is "not yet." Long-run historical comparisons do not rule out the possibility that deflation is negatively associated with economic growth-or, if one is prepared to hazard a causal interpretation, that deflation depresses growth. The inflation and deflation relevant to agents is notoriously difficult to measure. Tautologically, changes in the CPI will be relevant to consumers, while changes in the PPI will be relevant to producers, and it is not obvious, a priori, whether the behavior of producers or consumers is more immediately relevant in particular episodes of deflation. Prudence recommends considering both, as we have done in this paper. And when we consider both, evidence on the question posed by our title is decidedly mixed. 
The CPI yields very few episodes of persistent deflation in the post-World War II period, complicating efforts to conclusions about the potential effects of persistent deflation since the middle of the 20th century. There are more such episodes in the interwar period and the Great Depression in particular, causing CPI-based measures to suggest that the disruptive output effects of deflation are primarily a Great Depression-related phenomenon.

By comparison, PPI inflation is more volatile, including in the downward direction. There are more episodes of persistent deflation, including since the middle of the 20th century, when we use a PPI-based measure. According to our findings, changes in the PPI are significantly related to growth, in the direction anticipated by the disruptive-deflation hypothesis, not just in the interwar period but also and since World War II and possibly also under the classical gold standard, although the estimated effects are largest during the interwar period. ${ }^{16}$ This set of results also highlights the role of deflation in the Great Depression, but it is at odds with the view that deflation has been depressing only during the Great Depression. It does not overturn previous work that asset-price booms and slumps are important, but controlling for those booms and slumps does not alter our conclusions about the potential dangers of deflation.

Drawing strong conclusions from the post-World War II period-including negative conclusions about the absence of an association between CPI deflation and slow growth-may also be hazardous because of other special characteristics of this period. The immediate postwar years are marked by sharp swings between inflation and deflation and unusual spurts in economic growth as wartime controls are lifted and damage due to hostilities is repaired. Differences in levels of per capita GDP and therefore differences in the scope for catch-up growth are also greater in the second half of the 20th century and initial years of the 21st than in the interwar and classical gold standard years; failing to controls for these differences may also have unintended consequences for the results. In particular, we show that omitting the second half of the 1940s from the sample and controlling for per capita GDP (and hence for the scope for catch-up growth provides stronger evidence that CPI as well as PPI deflation has been negatively associated with economic growth in the post-World War II period.

It is important to acknowledge that high inflation as well as deflation can have a negative impact on economic growth, since this fact comes through clearly in the raw data, especially in the period since World War II. In addition, when we exclude episodes of high inflation, the negative association between not just PPI deflation but also CPI deflation and growth comes through more clearly.

In fact, inflation was the much larger concern in developing Asia until the recent emergence of deflation, especially producer price deflation, in some countries. In particular, producer prices have declined for 47 consecutive months as of February 2016 in the PRC, against the backdrop of a tangible moderation in economic growth since the global financial crisis. Our evidence suggests that it would be prudent for the region's monetary authorities to keep an eye on producer prices as well as consumer prices.

Again, analysis of correlations between deflation and growth in aggregate time series like those considered here will never definitively answer the question of whether the danger of deflation can be dismissed. But our analysis suggests, to paraphrase Mark Twain, reports of its demise have been greatly exaggerated.

16 Another caveat is that PPI inflation/deflation is significantly related to economic growth under the classical gold standard only at lower levels of confidence and only according to some specifications. 


\section{APPENDIX}

Table A.1: Data Availability

\begin{tabular}{|c|c|c|c|c|c|c|c|}
\hline Economy & Per Capita Real GDP & $\mathrm{CPI}$ & PPI & Stock Price & Property Price & Public Debt & Private Credit \\
\hline Argentina & 1875 & 1871 & 1914 & 1966 & - & 1870 & 1981 \\
\hline Australia & 1870 & 1871 & 1902 & 1875 & 1970 & 1870 & 1873-1939; 1953 \\
\hline Austria & 1870 & 1871 & 1871-1909; 1923 & 1922 & 2000 & 1880-1913; 1924-1937; 1948 & 1960 \\
\hline Belgium & 1870 & 1871 & 1871 & 1897 & 1970 & 1870 & 1970 \\
\hline Brazil & 1870 & 1871 & 1938 & 1992 & 2008 & 1870 & 1948-1949; 1988 \\
\hline Canada & 1870 & 1871 & 1871 & 1915 & 1970 & 1870 & 1871 \\
\hline Chile & 1870 & 1871 & 1929 & 1894 & 2002 & 1870 & 1962 \\
\hline PRC & 1929-1938; 1950 & 1971 & 1997 & 1990 & 2010 & 1982 & 1985 \\
\hline Colombia & 1870 & 1871 & 1949 & 1927 & 1988 & 1899 & 1950 \\
\hline Denmark & 1870 & 1871 & 1877 & 1914 & 1970 & 1880 & 1885-1938; 1951 \\
\hline Finland & 1870 & 1917 & 1914 & 1912 & 1970 & 1914 & 1950 \\
\hline France & 1870 & 1871 & 1871 & 1870 & 1970 & 1880-1931; 1949 & $1870-1938 ; 1950$ \\
\hline Germany & 1870 & 1871 & 1871 & 1870 & 1970 & 1880-1913; 1925-1938; 1951 & 1883-1913; 1925-1939; 1051 \\
\hline Greece & 1870 & 1915 & 1930 & 1952 & 1997 & $1870-1939 ; 1950$ & 1953 \\
\hline Hong Kong, China & 1950 & 1948 & 1994 & 1964 & 1979 & - & 1978 \\
\hline Ireland & 1921 & 1923 & 1939 & 1934 & 1970 & 1924 & 1948 \\
\hline Italy & 1870 & 1871 & 1871 & 1870 & 1970 & 1870 & 1870-1939; 1951 \\
\hline Japan & 1870 & 1871 & 1871 & 1914 & 1970 & $1872-1940 ; 1954$ & $1888-1939 ; 1953$ \\
\hline Republic of Korea & 1911 & 1913-1938; 1949 & 1931 & 1962 & 1975 & $1913-1938 ; 1970$ & 1962 \\
\hline Malaysia & 1911 & 1949 & 1987 & 1973 & 1988 & 1949-1957; 1970 & 1964 \\
\hline Mexico & 1895 & 1887 & 1887 & 1930 & 2005 & 1872 & 1948 \\
\hline The Netherlands & 1870 & 1871 & 1902 & 1890 & 1970 & 1870 & 1900 \\
\hline New Zealand & 1870 & 1908 & 1892 & 1926 & 1970 & 1870 & 1948 \\
\hline Norway & 1870 & 1871 & 1892 & 1914 & 1970 & 1880 & 1870 \\
\hline Peru & 1870 & 1901 & 1914 & 1926 & - & 1883 & 1980 \\
\hline Philippines & 1902 & 1900 & 1936 & 1952 & - & 1948 & 1948 \\
\hline Portugal & 1870 & 1931 & 1928 & 1931 & 1988 & 1870 & 1960 \\
\hline Singapore & 1900-1939; 1950 & 1949 & 1975 & 1965 & - & 1970 & 1963 \\
\hline South Africa & 1870 & 1896 & 1911 & 1910 & 1970 & 1870 & 1965 \\
\hline Spain & 1870 & 1871 & 1871 & 1874 & 1971 & 1870 & 1900 \\
\hline Sweden & 1870 & 1871 & 1871 & 1870 & 1970 & 1870 & 1871-1938; 1950 \\
\hline Switzerland & 1870 & 1881 & 1871 & 1910 & 1970 & 1880-1913; 1929 & 1906 \\
\hline Thailand & 1950 & 1949 & 1939 & 1992 & 1991 & 1913 & 1950 \\
\hline Turkey & 1923 & 1871 & 1931 & 1996 & 2010 & 1870 & 1986 \\
\hline United States & 1870 & 1871 & 1871 & 1870 & 1970 & 1870 & 1896 \\
\hline United Kingdom & 1870 & 1871 & 1871 & 1870 & 1970 & 1870 & 1880 \\
\hline Uruguay & 1870 & 1871 & 1964 & - & - & - & 1956 \\
\hline Venezuela & 1870 & 1901 & 1871 & 1929 & - & 1914 & 1950 \\
\hline
\end{tabular}

GDP = gross domestic product, $\mathrm{CPI}=$ consumer price index, $\mathrm{PPI}=$ producer price index, $\mathrm{PRC}=$ People's Republic of China. Source: Authors' compilation. 
Table A.2: Price Peaks

\begin{tabular}{|c|c|c|c|c|}
\hline Economy & $\mathrm{CPI}$ & PPI & Stock Price & Property Price \\
\hline Argentina & 1920 & 1920,1996 & & \\
\hline Australia & $1873,1882,1890,1902,1920,1929$ & $1902,1908,1919$ & $1888,1928,1950,1969,2007$ & \\
\hline Austria & $1884,1891,1929$ & $1871,1891,1924,1985,1994$ & $1975,1989,2006$ & \\
\hline Belgium & 1883,1929 & $1873,1881,1891,1926,1951,1957,1984$ & 1899, 1928, 1946, 1964, 1972, 1998, 2006 & 1980 \\
\hline Brazil & 1927 & & 2007 & \\
\hline Canada & $1874,1882,1920,1929$ & $1873,1890,1919,1951$ & $1928,1972,2007$ & 1994 \\
\hline Chile & & & 1995 & \\
\hline PRC & 1997 & 2004 & 2000,2007 & \\
\hline Colombia & 1928 & & 1997 & \\
\hline Denmark & $1874,1891,1901,1920$ & 1877, 1891, 1920, 1951 & 1919, 1927, 1946, 1965, 1972, 2007 & 1986, 2007 \\
\hline Finland & 1928 & $1920,1927,1951$ & $1919,1927,1973,1988,1999,2007$ & 1989 \\
\hline France & $1871,1877,1884,1901,1930$ & $1873,1890,1925,1951$ & 1881, 1890, 1899, 1928, 1962, 1972, 1999, 2007 & 1991 \\
\hline Germany & $1874,1881,1891,1928$ & $1873,1889,1928,1997$ & $1872,1881,1889,1899,1928,1946,1960,1969,1999,2007$ & 1983,1995 \\
\hline Greece & 1927 & & 1999,2007 & 2008 \\
\hline Hong Kong, China & 1997 & 1995 & $1972,1999,2007$ & 1981, 1997 \\
\hline Ireland & 1924 & 2000 & 2006 & 2007 \\
\hline Italy & $1874,1891,1926$ & $1874,1890,1900,1925,1948,2007$ & 1872, 1886, 1906, 1924, 1961, 1969, 1986, 2000, 2006 & 1993,2008 \\
\hline Japan & $1881,1920,1998,2008$ & $1881,1919,1956,1982,2008$ & $1919,1960,1972,1989,1999,2006$ & 1991 \\
\hline Republic of Korea & 1920 & & 1999 & 1991 \\
\hline Malaysia & & 2007 & 1983,1993 & 1997 \\
\hline Mexico & & $1889,1920,1927$ & & \\
\hline The Netherlands & $1877,1891,1920$ & 1919,1951 & 1890, 1898, 1919, 1928, 1947, 1968, 1999, 2007 & 1978,2008 \\
\hline New Zealand & 1920 & $1893,1898,1906,1920$ & $1972,1986,1996,2006$ & \\
\hline Norway & $1874,1891,1900,1920$ & $1893,1900,1920$ & $1919,1957,1973,2007$ & 1988 \\
\hline Peru & 1920 & 1920 & & \\
\hline Philippines & 1946 & 1948,2008 & & \\
\hline Portugal & & 1928,1952 & 1989, 1999, 2007 & 2007 \\
\hline Singapore & & 1980 & $1983,1993,1999,2007$ & \\
\hline South Africa & 1902,1920 & 1920 & & \\
\hline Spain & $1882,1898,1920$ & $1877,1907,1920$ & 1882, 1889, 1900, 1927, 1947, 1956, 1973, 2007 & 2007 \\
\hline Sweden & $1874,1891,1920$ & $1873,1891,1900,1919$ & $1872,1906,1919,1928,1999,2006$ & 1991 \\
\hline Switzerland & $1882,1892,1898,1919$ & $1873,1890,1919,1951,1974,1992,2008$ & $1919,1928,1961,1972,1986,2000,2006$ & 1989 \\
\hline Thailand & & & 1993 & 1997 \\
\hline Turkey & 1929 & & & \\
\hline United States & $1872,1881,1891,1920$ & 1872,1919 & $1872,1881,1892,1928,1972,1999,2007$ & 2007 \\
\hline United Kingdom & $1873,1891,1898,1920$ & 1872,1919 & $1873,1898,1928,1946,1972,1999,2007$ & 1989,2007 \\
\hline Uruguay & 1931 & & & \\
\hline Venezuela & & $1872,1890,1920,1926$ & & \\
\hline
\end{tabular}

$\mathrm{GDP}=$ gross domestic product, $\mathrm{CPI}=$ consumer price index, $\mathrm{PPI}=$ producer price index, $\mathrm{PRC}=$ People's Republic of China.

Source: Authors' compilation. 


\section{Table A.3: Data Sources}

\begin{tabular}{|c|c|c|}
\hline Variables & Sources & Economies/Years \\
\hline \multirow[t]{2}{*}{ CPI } & International Financial Statistics, IMF & $\begin{array}{l}\text { People's Republic of China (1971 1979), Greece } \\
\text { (1915 1922), Republic of Korea (1913 1938), New Zealand } \\
\text { (1908 1914), Philippines (1942 1943). } \\
\text { Colombia (2008 2009). }\end{array}$ \\
\hline & Global Financial Database & All other years, all other countries. \\
\hline \multirow[t]{2}{*}{ PPI } & International Historical Statistics & $\begin{array}{l}\text { Austria (1870 1923), Belgium (1870 1913), Finland } \\
\text { (1913 1920), Germany (1921 1923), Greece (1947 1948), } \\
\text { Ireland (1939 1945), Italy (1870 1910, 1913 1914), New } \\
\text { Zealand (1891 1913), Norway (1892 1977), Peru } \\
\text { (1913 1980), Portugal (1928 1932), Thailand (1939 1947), } \\
\text { Uruguay (1963 1966). }\end{array}$ \\
\hline & Global Financial Database & All other years, all other countries. \\
\hline \multirow{3}{*}{ Equity prices } & Shularick and Taylor (2012) & $\begin{array}{l}\text { Canada (1915 1991), France (1994 2008), Germany } \\
\text { (1870 1917), Italy (1870 1904), The Netherlands } \\
\text { (1890 1918), Norway (1914 1968), Spain (1874 1984), } \\
\text { Sweden (1870 1900). }\end{array}$ \\
\hline & Bloomberg & $\begin{array}{l}\text { France (2009 2014), Portugal (2007 2014), Venezuela } \\
\text { (2006 2014). }\end{array}$ \\
\hline & Global Financial Database & All other years, all other countries. \\
\hline \multirow{2}{*}{ Property prices } & Residential property price statistics, BIS & Hong Kong, China; Republic of Korea; Malaysia; Thailand. \\
\hline & OECD & All other years, all other countries. \\
\hline \multirow{2}{*}{$\begin{array}{l}\text { Real GDP per } \\
\text { capita }\end{array}$} & World Development Indicators & $2011 \sim 2014$ \\
\hline & Maddison project & All other years, all other countries. \\
\hline \multirow{3}{*}{ Government debt } & $\begin{array}{l}\text { Carmen Reinhart; Total (domestic plus } \\
\text { external) gross general government } \\
\text { debt/GDP }\end{array}$ & Italy, The Netherlands, New Zealand. \\
\hline & World Economic Outlook (IMF) & $2011 \sim 2014$ \\
\hline & $\begin{array}{l}\text { Carmen Reinhart; Total (domestic plus } \\
\text { external) gross central government } \\
\text { debt/GDP }\end{array}$ & All other years, all other countries. \\
\hline \multirow{3}{*}{ Private credit } & $\begin{array}{l}\text { Shularick and Taylor (2012); Credit to } \\
\text { the nonfinancial sector, BIS }\end{array}$ & $\begin{array}{l}\text { Australia, Canada, Denmark, France, Germany, Italy, Japan, } \\
\text { The Netherlands, Norway, Spain, Sweden, Switzerland, } \\
\text { United States, United Kingdom. }\end{array}$ \\
\hline & $\begin{array}{l}\text { International Financial Statistics, IMF; } \\
\text { Credit to the nonfinancial sector, BIS }\end{array}$ & $\begin{array}{l}\text { Argentina, Brazil, Chile, Colombia, Finland, Greece, Ireland, } \\
\text { Mexico, New Zealand, Peru, Philippines, Singapore, Thailand, } \\
\text { Uruguay, Venezuela. }\end{array}$ \\
\hline & Credit to the nonfinancial sector, BIS & $\begin{array}{l}\text { Austria; Belgium; People's Republic of China; Hong Kong, } \\
\text { China; Republic of Korea; Malaysia; Portugal; South Africa; } \\
\text { Turkey. }\end{array}$ \\
\hline
\end{tabular}

$\mathrm{BIS}=$ Bank for International Settlements, $\mathrm{CPI}=$ consumer price index, GDP = gross domestic price, IMF = international Monetary Fund, $\mathrm{OECD}=$ Organisation for Economic Co-operation and Development, $\mathrm{PPI}=$ producer price index .

Source: Authors' compilation. 


\section{REFERENCES}

Akeson, Andrew, and Patrick Kehoe. 2004. "Deflation and Depression: Is There an Empirical Link?" American Economic Review 94 (2): 99-103.

Bordo, Michael, and Angela Redish. 2004. "Is Deflation Depressing? Evidence from the Classical Gold Standard." In Deflation: Current and Historical Perspectives, edited by Richard Burdekin and Pierre Siklos. Cambridge: Cambridge University Press.

Borio, Claudio, Magdalena Erdem, Andrew Filardo, and Boris Hofmann. 2015. "The Cost of Deflations: A Historical Perspective." BIS Quarterly Review (March): 31-54.

Borio, Claudio, and Andrew Filardo. 2005. "Deflation and Monetary Policy in a Historical Perspective: Remembering the Past or Being Condemned to Repeat It?" Economic Policy 20 (44): 800-44.

Fackler, James, and Randall Parker. 2005. "Was Debt Deflation Operative during the Great Depression?" Economic Inquiry 43 (1): 67-78.

Fisher, Irving. 1933. “The Debt-Deflation Theory of Great Depressions.” Econometrica 1 (4): 337-57.

Friedman, Milton, and Anna Schwartz. 1963. A Monetary History of the United States, 1867-1960. Princeton: Princeton University Press for the National Bureau of Economic Research.

Hodrik, Robert. 2014. The Empirical Evidence on the Efficiency of Forward and Futures Foreign Exchange Markets. Harwood Fundamentals of Pure and Applied Economics. London: Routledge.

Messina, Julian, Chiara Strozzi, and Jarkko Turunen. 2009. "Real Wages over the Business Cycle: OECD Evidence from the Time and Frequency Domains." European Central Bank Working Paper Series No. 1003.

Mitchell, Brian. R. 1993. International Historical Statistics. New York: Stockton Press.

Schularick, Moritz, and Alan Taylor. 2012. "Credit Booms Gone Bust: Monetary Policy, Leverage Cycles, and Financial Crises, 1870-2008." American Economic Review 102 (2): 1029-61.

Siklos, Pierre, and Yang Zhang. 2010. "Identifying the Shocks Driving Inflation in China." Pacific Economic Review 15 (2): 204-23.

Swanson, Eric T. 2004. "Measuring the Cyclicality of Real Wages: How Important is the Firm's Point of View?" The Review of Economics and Statistics 86 (1): 362-77.

US Bureau of Labor Statistics. 1966. “Wholesale Prices.” Handbook of Labor Statistics, pp.10-11.

- 2016. "Producer Price Indices: Frequently Asked Questions." Washington, DC: Bureau of Labor Statistics. http://www.bls.gov/ppi/ppifaq.htm.

Warren, George, and Frank Pearson. 1933. Prices. New York: George Wiley and Sons. 


\section{Deflation in Asia: Should the Dangers Be Dismissed?}

Deflation has emerged as a new concern for Asian policy makers. The traditional view is that deflation can lead to a vicious cycle of falling demand and prices. However, another school of thought emphasizes the role of positive supply shocks and takes a more benign view. Using consumer prices, Borio et al. (2015) examine the relationship between deflation and economic growth, and find some evidence which casts doubt on the traditional view. Using both consumer prices and producer prices, the authors revisit the relationship and find stronger grounds for concern about the harmful effect of deflation on growth.

\section{About the Asian Development Bank}

ADB's vision is an Asia and Pacific region free of poverty. Its mission is to help its developing member countries reduce poverty and improve the quality of life of their people. Despite the region's many successes, it remains home to the majority of the world's poor. ADB is committed to reducing poverty through inclusive economic growth, environmentally sustainable growth, and regional integration.

Based in Manila, ADB is owned by 67 members, including 48 from the region. Its main instruments for helping its developing member countries are policy dialogue, loans, equity investments, guarantees, grants, and technical assistance. 